MACIEJ JANOWSKI

Instytut Historii PAN, Warszawa

\title{
MAŁŻEŃSTWO Z ROZSĄDKU: KATOLICYZM I NOWOCZESNOŚĆ W DZIEWIĘTNASTOWIECZNEJ EUROPIE
}

Chciałbym zastanowić się nad współzależnością przemian europejskiego chrześcijaństwa - przede wszystkim katolicyzmu - w ciągu XIX w. i dokonujących się na kontynencie najróżniejszych procesów modernizacyjnych. Będę przypatrywał się tym problemom pod kątem zagadnienia dechrystianizacji.

Zacznę od pytania najogólniejszego: Co takiego stało się z chrześcijaństwem w ciągu XIX w.? Czy w ogóle stało się coś specyficznego, innego niż w ciągu dowolnej innej epoki? Wyglądało inaczej w roku 1914 niż w 1789 r., to pewne; ale wszystko przecież wygląda inaczej na początku niż na końcu każdego odpowiednio długiego odcinka czasu. Kiedy próbuję sobie uprzytomnić naturę samego problemu, wtedy natychmiast pojawia się cała masa wątpliwości - zanim jeszcze w ogóle dojdę do materiału faktograficznego. Tak więc - o co właściwie pytamy? Poniżej spróbuję przedstawić kilka perspektyw, z których można oglądać interesujące nas zjawisko ${ }^{1}$.

${ }^{1}$ Niniejszy tekst, na różnych etapach swojego powstawania, był dogłębnie dyskutowany w Zakładzie Historii Idei i Dziejów Inteligencji Instytutu Historii im. Tadeusza Manteuffla PAN. Krytyczne głosy wszystkich dyskutantów ogromnie mi pomogły i wpłynęły na ostateczny kształt tekstu (za błędy oczywiście odpowiadam sam). Szczególnie chciałbym podziękować Maciejowi Górnemu, Jerzemu Jedlickiemu, Adamowi Kożuchowskiemu i Krzysztofowi Niewiadomskiemu (który przekazał mi obszerne uwagi na piśmie). 


\section{Dziewiętnastowieczna modernizacja} i chrześcijaństwo

a) Zacznijmy od przemian indywidualnych przeżyć religijnych w ciągu interesującego nas stulecia (z okładem). Przyjmijmy apriorycznie, że rozkład postaw psychicznych jest taki sam w różnych epokach: proporcje ludzi gorących i letnich, emocjonalnych i racjonalnych, skrajnych i umiarkowanych są takie same w wieku dziewiętnastym, jak w każdym innym (choć nawet to nie jest całkiem pewne: przypomnijmy sobie, co pisał Johan Huizinga o większej niż dzisiejsza emocjonalności ludzi późnego średniowiecza). Mamy wiele świadectw z XIX w., jak zresztą z każdej epoki, przeżyć ludzi o pogłębionym życiu religijnym. Możemy zajrzeć do pamiętników generałowej Jadwigi Zamoyskiej albo - by przywołać kogoś z innej sfery społecznej - do dzienników lwowskiej pisarki Zofii Romanowiczówny². Bardzo ciekawym źródłem jest niewielka praca Elżbiety Dębickiej pt. Genealogia psychiczna, starająca się zanalizować - przy użyciu psychologicznych teorii charakterologicznych dwudziestolecia międzywojennego profile psychiczne przodków autorki, wywodzących się ze środowiska polskiego ziemiaństwa. Problem osobistej religijności powraca w tej pracy w wielu analizach ${ }^{3}$. Ludzie tacy jak bohaterowie przykładowo wspomnianych książek to wszystko są osoby, które swoją religijność przeżywają „,do siebie", co nie znaczy, że są bierne. Żyją, ponoszą ofiary i wyrzeczenia w imię swej religii, swe cierpienia ofiarują Panu Bogu - i nikt o tym nie wie, jeśli one same, albo ich najbliżsi, nie utrwalą takich form religijności na kartach dzienników czy wspomnień. Zapewne religijność takich ludzi miał na myśli Alfred Whitehead, pisząc, że religia to „to, co człowiek robi ze swoją samotnością" ". Oczywiście istnieją także ludzie religijni w bardziej „ekstrawertyczny” sposób, których indywidualnie pogłębiona religijność przekłada się na poczucie odpowiedzialności społecznej i często również na działalność publiczną prowadzoną w imię haseł religijnych - tacy są łatwiejsi do zbadania, gdyż pozostawiają więcej źródeł.

Przeżycia psychiczne jednostek nie dzieją się poza historią. Istnieją formy duchowości specyficzne dla danej epoki, a więc tak czy inaczej zależne od właściwego dla niej typu kultury. Czasy romantyzmu są świadkiem odrodzenia emocjonalności religijnej (byłoby ciekawe zbadać, jak ma się ta fala emocjonalności religijnej do fal poprzednich: religijności barokowej

${ }^{2}$ J. Zamoyska, Wspomnienia, oprac. M. Czapska, Londyn 1961; Z. Romanowiczówna, Dziennik lwowski 1842-1930, oprac. Z. Sudolski, Warszawa 2005, t. 1-2.

${ }^{3}$ E. Dębicka, Genealogia psychiczna, wyd. J. Komorowski, Wrocław 2012.

${ }^{4}$ Definicję Whiteheada cytuje Gordon W. Allport, Jednostka i religia (oryg. ang. 1950), w: idem, Osobowość i religia, Warszawa 1988, s. 144. 
XVII w.i późnośredniowiecznej devotio moderna). Badacze zwracają uwagę na wzrost liczby objawień prywatnych, zwłaszcza maryjnych ${ }^{5}$, które charakteryzują się pewnymi cechami specyficznymi. Matka Boska objawia się przedstawicielom grup zmarginalizowanych: kobietom i dzieciom ze środowiska wiejskiego czy małomiasteczkowego, często przedstawicielom mniejszości narodowych. Objawienia w Lourdes są tego najlepszym przykładem; na ziemiach polskich wszystkim powyższym cechom odpowiadają np. objawienia w Gietrzwałdzie na Warmii w 1877 r. Również w ciągu XIX w. rozwija się praktyka misji w parafiach; misje takie dawały często okazje do manifestacji zbiorowych emocji religijnych na dużą skalę. Mamy wiele świadectw, jak emocjonalnie reagowali ich uczestnicy na słowa, gesty, ton głosu popularnych kaznodziejów; w jakiej mierze ten nastrój trwał dalej, w jakiej zaś ulatniał się w chwilę po zakończeniu nabożeństwa, nie jest jasne ${ }^{6}$.

Zastanawiając się nad znaczeniem przemian religijności indywidualnej dla tematu niniejszego szkicu, trzeba poruszyć jeszcze dwie kwestie. Jeśli bowiem pytamy o chrystianizację czy dechrystianizację, to pojawia się problem: Czy zjawiska te zawarte są w indywidualnych procesach psychicznych, czy w przemianach społecznych? Że indywidualne życie religijne zakorzenione jest w zjawiskach społecznych, wiemy przynajmniej od Émile'a Durkheima, ale tu chodzi o coś innego: Czy jeśli instytucjonalny ruch religijny wzrasta w siłę, a liczba osób, które mają indywidualne przeżycia religijne, maleje, to czy mamy do czynienia z chrystianizacją, czy dechrystianizacją (na dłuższą metę)? Czy możemy uznać, że procesy społeczne NIE są wieloma procesami indywidualnymi, albo też uznać, że mówiąc o (de)chrystianizacji, mamy na myśli zjawisko społeczne, a nie psychologiczne? Czy możemy sobie wyobrazić (modelowo) społeczeństwo w którym NIKT nie jest wewnętrznie religijny, a społeczeństwo jest religijne, bo ludzie „odgrywają rolę" religijną w odpowiednich momentach, albo przynajmniej nie oponują, gdy inni ją odgrywają? Albo odwrotnie, społeczeństwo, w którym wszyscy są wewnętrznie głęboko religijni, ale reprezentują religijność typu pietystycznego, ukierunkowaną na pogłębione przeżycia indywidualne? Takie społeczeństwo jako całość nie będzie jednak religijne, bo nie ma wielkich publicznych uroczystości

${ }^{5}$ Gábor Klaniczay przedstawił swoje badania nad dziewiętnastowieczną religijnością ekstatyczną w bardzo ciekawym wykładzie wygłoszonym na wydziale historycznym Central European University w Budapeszcie (13 XI 2014). Wykładowi temu zawdzięczam zwrócenie uwagi na omawiany problem. O wzroście popularności objawień prywatnych w XIX w. por. także D. Olszewski, Kultura i życie religijne społeczeństwa polskiego w XIX wieku, Lublin 2014, s. 274-276.

${ }^{6}$ Przykłady daje Daniel Olszewski, op. cit., s. 240-255. 
religijnych, bo państwowy ceremoniał jest świecki, a z zewnątrz nie widać, czy obywatele przestrzegają norm społecznych dlatego, że boją się kary, czy może dlatego, że mają wysoką świadomość obywatelską, czy też dlatego, że mają głęboko uwewnętrznione normy moralne ich religii. Takie ujęcie modelowe jest absurdalne, bez wątpienia, ale chodzi o to, aby uzmysłowić, sobie i czytelnikowi, że indywidualne życie religijne i społeczne celebrowanie religii to dwa różne zjawiska i że ich dynamika, do pewnego stopnia, jest odmienna, a nawet przeciwstawna ${ }^{7}$.

I druga, zbliżona kwestia: wbrew często powtarzanemu (choć pewnie raczej w publicystyce niż w literaturze naukowej) zdroworozsądkowemu przekonaniu, że niezachwiana pewność własnych racji prowadzi do fanatyzmu, wydaje mi się, że jest odwrotnie - do fanatyzmu prowadzi niepewność siebie. Najbardziej nietolerancyjni wobec jakiegoś zachowania są ci, którzy mają kłopot z podporządkowaniem się dotyczącemu go zakazowi, którego przestrzeganie osiągają jedynie z wielkim trudem - pisał Elliot Aronson ${ }^{8}$. Gordon Allport, być może nieco idealistycznie, odniósł podobne spostrzeżenie do problemu religii, pisząc, że fanatyzm religijny jest jednym $z$ centralnych znamion religijności niedojrzałej ${ }^{9}$. Człowiek bądź grupa niezachwianie pewna słuszności swego światopoglądu może być tolerancyjna (czy to nie przypadek słabości tendencji do prozelityzmu w judaizmie?). Jeśli uznamy tę obserwację za trafną (przynajmniej w części przypadków), to byłaby ona argumentem na rzecz tezy o rozłączności religijności indywidualnej i religijności jako zjawiska społecznego, ponieważ z fanatycznych i nietolerancyjnych zachowań przedstawicieli jakiegoś wyznania w sferze społecznej nie można wnioskować o głębi ich wiary.

Świadectwa indywidualnych przeżyć są bardzo trudne do uogólnień. Mówią one coś historykowi w tym jedynie (albo aż w tym) sensie, że pozwalają w jakiś intuicyjny sposób wyczuć nieostre granice możliwego w danej epoce: jeśli mamy choć jeden jedyny przykład danej postawy, to tyle tylko możemy z pewnością wywnioskować, że taka postawa była w tej epoce możliwa. Jak częsta, nie wiemy, ale możliwa. To już coś, bo pozwala nam to rekonstruować skalę możliwych zachowań: z nieskończonej płaszczyzny

${ }^{7}$ Teoretyczne rozważania na ten temat wraz z omówieniem olbrzymiej literatury przedmiotu znajdziemy w przeglądowych pracach dotyczących socjologii religii, np. K. Zielińska, Spory wokół teorii sekularyzacji, Kraków 2009; G. Kehrer, Wprowadzenie do socjologii religii, Kraków 2006 (oryg. niem. 1988), (wyd. 2).

${ }^{8}$ E. Aronson, Człowiek - istota społeczna, Warszawa 1978 (oryg. ang. 1972).

${ }^{9}$ G.W. Allport, op. cit. s. 151 (obserwacja ta jest u Allporta częścią bardzo ciekawej i rozbudowanej analizy różnych form dojrzałej i niedojrzałej religijności; kwestie te musimy tu jednak pominąć). 
wszelkich teoretycznie możliwych ludzkich postaw wydzielić ograniczony obszar, wewnątrz którego mieścić się będą zachowania i odczucia spotykane w interesującej nas epoce i kulturze. Podsumowując ten punkt nie wydaje się, aby w sferze indywidualnego życia religijnego rozumianego jakościowo widoczny był w owej epoce jakikolwiek kryzys chrześcijaństwa. Inną sprawą jest kwestia ilościowa: jak wielka była grupa osób niedostępna jakimkolwiek przeżyciom religijnym? To pytanie prowadzi nas w stronę następnego problemu.

b) Osobno potraktować należy przemiany intelektualne, ważne zarówno jako procesy indywidualne, jak i społeczne. Mówiąc o procesach intelektualnych, nie mam na myśli, że ktoś odkrył racjonalne powody niewiary (bo powodów takich, podobnie jak i racjonalnych powodów wiary, nie ma). Mam na myśli stworzenie takiej atmosfery intelektualnej/ kulturowej, w której coraz więcej rzeczy może/powinno być analizowanych bez użycia założeń religijnych. W średniowieczu na każdy temat można było myśleć i pisać w ramach kategorii religijnych. Nie chodzi o to, że religia zawężała środkami represyjnymi możliwą sferę myśli i wypowiedzi (choć pewnie też), ale odwrotnie - że paradygmat religijny był tak szeroki i tak intelektualnie atrakcyjny, że w jego ramach dawało się pisać o wszystkim, co mogło być dla europejskiego intelektualisty tamtych wieków interesujące. Warto tu przypomnieć jedną z klasycznych książek szkoły Annales - Le problème de l'incroyance au XVI siècle Luciena Febvre'a (1947). Jeden z głównych argumentów brzmi, że w szesnastowiecznej kulturze francuskiej nie można było być ateistą - nie było kategorii do wyrażenia ateizmu. Teza wzbudziła polemiki, ale dla niniejszego tematu jest po prostu przydatna myślowo jako uwidocznienie pewnego problemu: w różnych kulturach idee niereligijne wyrazić jest łatwiej lub trudniej, i w kulturze dziewiętnastowiecznej było coraz łatwiej.

Weźmy do ręki jedną z najbardziej wpływowych książek krytykujących religię w imię postępu rozumu - History of the Conflict Between Religion and Science amerykańskiego biologa Johna Williama Drapera, opublikowaną w 1874 r., a wkrótce przetłumaczoną na jęz. francuski, niemiecki, włoski, hiszpański, polski, rosyjski, portugalski i serbski ${ }^{10}$. Jeśli spróbować (jak zalecałby Wilhelm Dilthey i inni teoretycy humanistyki rozumiejącej) wmyśleć się w postawę inteligentnego czytelnika tej książki w ósmej czy dziewiątej dekadzie XIX w., to wtedy można dojść do wniosku, że jej efekt perswazyjny wynika z dwóch rzeczy: po pierwsze, z ogromu materiału faktograficznego. Obok frazeologii pochodzącej z oświeceniowego

${ }^{10}$ O. Chadwick, The Secularization of the European Mind in the 19th Century, Cambridge 1990 (1 wyd. 1975), s. 161. 
antyklerykalizmu czytelnik napotyka cała masę przejrzyście zorganizowanych danych rzeczowych; książka, niezależnie od jej polemicznego charakteru, musiała mieć w swoim czasie wartość jako popularyzacja ówczesnego stanu nauk przyrodniczych. Materiał ten na niespecjaliście w dziedzinie owych nauk (a takim jest zarówno piszący te słowa, jak i większość dziewiętnastowiecznych czytelników Drapera) musiał robić wrażenie.

To było coś nowego. „Nauka udowadnia, że religia jest fałszywa” było myślą świeżą, która nie zdążyła się jeszcze zbanalizować w popularnej propagandzie antyklerykalnej. Dawniejszy antyklerykalizm celował w moralne nadużycia kleru, w ograniczanie przez Kościół swobody seksualnej i każdej innej, w fałszerstwa ksiąg świętych i niezgodność ich obrazu historii z metodą krytycznej analizy źródeł - teraz zaś mogło się wydawać, że znaleziono argument o wiele bardziej druzgoczący, przemawiający samą spokojną siłą faktów, bez odwoływania się do sumienia, bez retoryki itp. Co więcej - przecież aż dotąd argument ten (znany jako argument kosmologiczny) był jednym z czołowych argumentów zwolenników teizmu. Teraz zaś - użyjmy militarnej retoryki - jedna z najcięższych armat na przedpolach twierdzy została zdobyta przez atakujących, przestawiona o 180 stopni i skierowana przeciw samym obrońcom. To prawda - istniały antecedencje. Sens argumentu kosmologicznego podał w wątpliwość już David Hume w XVIII w. (w jego Dialogues Concerning Natural Religion). Z czysto rozumowego punktu widzenia argumenty Hume'a były głębsze niż argumenty jakiegokolwiek dziewiętnastowiecznego antyklerykała, ale podane były na typową dla Hume'a modłę: spokojnie, nieagresywnie, lekko ironicznie. Nie mogły masowo oddziaływać. Przy tym Hume'owski sceptycyzm dotyczył prawomocności poznania naukowego w tym samym stopniu co religijnego, więc nie mógł dostarczyć owego retorycznie bardzo efektownego przeciwstawienia prawdziwej nauki i fałszywej religii, na którym zbudowana jest książka Drapera.

Po drugie, u Drapera wyraźnie widać możliwość interpretacji idei postępu jako argumentu antyreligijnego. To także samo w sobie nie jest nowe (przypomnijmy Nicolasa de Condorceta), ale tutaj także ów zmasowany materiał faktograficzny dodaje argumentacji „z postępu” mocy, której nie miała jeszcze w końcu XVIII w. Nawet jeśli antyreligijni autorzy z XIX w. mówią podobne rzeczy co przedstawiciele oświecenia w XVIII w. - pisze Owen Chadwick - to siły perswazyjnej nadaje im fakt, że nie są ludźmi oświecenia, ale ludźmi laboratorium ${ }^{11}$ : Nauka (przez duże „N”) sama przemawia przez ich usta. Osiągnięcia nauki wieku XIX pozwalają na pewien

${ }^{11}$ O. Chadwick, op. cit., s. 165. 
sposób pisania, w którym duma z własnych dokonań łączy się z charakterystycznym zdumieniem połączonym $\mathrm{z}$ pogardą $\mathrm{w}$ odniesieniu do poprzednich pokoleń, a także do tych w naszych czasach, którzy jeszcze nie wyzwolili się z przesądów. „Nie bez zdziwienia możemy spoglądać wstecz na to, co wówczas było szeroko uznawane za kryteria prawdy. Doktryny były uważane za udowodnione przez wielką liczbę męczenników, którzy je wyznawali, poprzez cuda, zeznania demonów, szaleńców lub ludzi opętanych przez złe duchy. [- - ] Co za głęboka ignorancja natury dowodu i jego zasad!"12.

Taki sposób perswazji oddziaływał; tworzył nową rzeczywistość kulturową, pozwalał przyjąć nowe idee aktem wiary raczej niż rozumu, ale z miłym przekonaniem, że w istocie są one racjonalnie ugruntowane. Korespondował zarazem z nastrojem ówczesnej liberalnej historiografii, która również wielokrotnie dawała wyraz swojemu zdumieniu, że ludzie w dawnych epokach mogli tak łatwo poddawać się tyrańskim instytucjom (wśród których Kościół katolicki zajmował jedno z czołowych miejsc). Można by jeszcze analizować olbrzymi wpływ teorii ewolucji Karola Darwina (nie w pełni zgodny z intencjami jej twórcy) i otwarcie krytykujące religię idee niemieckiego fizjologa Jacoba Moleschotta, czy wybitnego przyrodnika Ernsta Haeckla. To one sprawiły, że Madzia Brzeska w Emancypantkach (poznawszy je od pewnego zblazowanego kolegi) zaczęła w chwili zwątpienia zastanawiać się, czy może rzeczywiście duszy nie ma, a o wszystkim decyduje „fosfór”, z którego zbudowany jest nasz mózg? Pewien angielski czternastolatek w latach osiemdziesiątych XIX w., cytowany przez Chadwicka, zapisał w swym dzienniku: „Darwin has disproved the Bible!”"13. Sytuacja kulturowa, w której inteligentny uczeń odczuwa takie przekonanie, jest doskonałym przejawem osłabienia wpływów chrześcijaństwa.

Świadectw podobnych postaw mamy ogromnie wiele, rzecz ciekawa - nie tylko wśród tryumfująco nastawionych pozytywistów, ale także wśród osób, które martwiły się (czasem nawet rozpaczały) z powodu niemożliwości wiary w racjonalnej epoce. Spotykamy je - rzecz jeszcze ciekawsza - wśród samych chrześcijan, którzy uznają, że nauka nie pozwala wierzyć tak jak dawniej - i wyciągają z tego najróżniejsze wnioski.

12 „Not without astonishment can we look back at what, in those times, were popularly regarded as criteria of truth. Doctrines were considered as established by the number of martyrs who had professed them, by miracles, by the confession of demons, of lunatics, or of persons possessed of evil spirits [- - . What an utter ignorance of the nature of evidence and its laws have we here!", J.W. Draper, History of the Conflict Between Religion and Science, New York 1875, s. 205-206.

${ }^{13}$ O. Chadwick, op. cit., s. 164 (bez podania źródła informacji ani nazwiska owego czternastolatka). 
Jak to się stało? Czy pytając o mechanizm i przyczyny dechrystianizacji, nie pytamy tym samym o mechanizm i przyczyny zmiany w historii - najtrudniejszej może i najbardziej niewyjaśnialnej rzeczy? Jeśli szukać tu jakiegoś wyjaśnienia, to chyba trzeba jednak wrócić do starej tezy o zasadniczo scjentystyczno-optymistycznym usposobieniu dominującym w XIX w. Ten obraz - prawda - tak łatwy jest do podważenia. Nie tylko jeśli popatrzy się na pesymistów i sceptyków, ale nawet jeśli wczyta się dokładniej w pisma klasyków wiktoriańskiego liberalizmu, autorów takich jak John Stuart Mill czy Herbert Spencer, widzimy ich wątpliwości, a chwilami przerażenie kierunkiem rozwoju cywilizacji. Niemniej w porównaniu z czasami wcześniejszymi i późniejszymi wydaje się, że epoka od oświecenia do ostatnich dekad XIX w. rzeczywiście odznaczała się pewną szczególną dozą optymizmu co do możliwości rozwojowych człowieka (świadomie odkładamy na razie romantyzm na stronę).

Można też przedstawić bardziej skomplikowany obraz, który na pierwszym planie ukazywałby zwątpienie jako jedno z podstawowych doświadczeń wykształconego człowieka w XIX w. Owo zwątpienie, a nie naiwny optymizm, byłoby efektem rozwoju nauki ${ }^{14}$. Dopiero w efekcie przepracowania owego kryzysu wywołanego zwątpieniem można było dojść do optymistycznej wiary w naukę (bądź też do pogłębionej religijności). Idea postępu pozwalała na przywrócenia zakłóconego poczucia ładu świata. Tworzą się więc całe subkultury, w których niewiara a przynajmniej odrzucenie wyznaniowych ortodoksji - jest dopuszczalna albo nawet stanowi normę. Na pewno taką subkulturę stanowiły na przełomie XIX i XX w. środowiska młodej inteligencji w różnych krajach europejskich, środowiska zwolenników wielu nowych prądów politycznych (przede wszystkim socjaldemokracji), na pewno także środowiska artystyczne i duża część środowisk naukowych.

Poruszone powyżej zagadnienie postępu wprowadza nas w drugi jeszcze, obok scjentyzmu, kluczowy dla naszego tematu nurt dziewiętnastowiecznej kultury, mianowicie historyzm. Zjawiska religijne, jak i wszystkie inne, poddane zostają „, historyzacji” - ów neologizm znaczy z grubsza tyle, że na wszelkie zjawiska patrzy się teraz jak na właściwe dla swojej epoki i swojej kultury. Z jednej strony oznacza to, iż nie należy ich krytykować z punktu widzenia epok późniejszych, ale trzeba zrozumieć je w ich własnych kategoriach, z drugiej zaś, iż winno się je relatywizować - uznawać, że dana postać, ruch społeczny, idea, są w nieprzekraczalny sposób przy-

${ }^{14}$ Por. J. Jedlicki, Świat zwyrodniały. Lęki i wyroki krytyków nowoczesności, Warszawa 2000, szczególnie podrozdział „Ewolucja a postęp moralny” (s. 139-184). 
wiązane do swojej epoki. Takie podejście w odniesieniu do chrześcijaństwa owocuje jedną z najsławniejszych - obok Drapera czy Haeckla - obrazoburczych książek XIX w., Życiem Jezusa Ernesta Renana. Tę książkę, wraz z Haecklem i wieloma innymi, czytał w przededniu pierwszej wojny światowej bohater Nieba w płomieniach Jana Parandowskiego: „Podtrzymywała go w tej lekturze niespokojna ciekawość i szczególny rodzaj złośliwości, z jaką teraz przyjmował wszystko, co mogło się przyczynić do pognębienia wiary. W osobnym kajecie robił notatki, które wciąż odczytywał, aby je utrwalić w pamięci. Mieszały się tam z sobą sprzeczności dostrzeżone w ewangeliach, kłopotliwe analogie obrzędów pogańskich z chrześcijańskimi, fakty historyczne nie dające się pogodzić z tradycją Kościoła, nie rozstrzygnięte pytania"15.

Jeśli młodzi ludzie mogli - mimo dezaprobaty otoczenia - czytać podobne książki i akceptować ich wnioski, to dzieje się tak dlatego, że - jak pisze jeden z najwybitniejszych współczesnych socjologów religii, Peter Berger - nowoczesność rozróżnia ${ }^{16}$. Wprowadza rozmaite możliwości, otwiera drogi postępowania wcześniej niedostępne. (Nie miejsce tutaj na zastanawianie się, jak ma się ta teza do znanej tezy Zygmunta Baumana, że nowoczesność ujednolica, przetwarza świat w ściśle zaplanowany i zgeometryzowany ogród francuski. Myślę, że nie są one sprzeczne, lecz dotyczą innych zagadnień). Właśnie w kategoriach otwarcia innych, niedostępnych dotąd dróg rozwoju umysłowego (z których najważniejsze zasygnalizowano powyżej) leży potencjalnie dechrystianizacyjny charakter kultury XIX w. Potencjalnie - bo otwarcie dróg nie przesądza jeszcze, jak wiele osób je wybierze.

A teraz przechodzimy do następnej epoki. Gdzieś w ostatniej dekadzie wieku XIX racjonalny optymizm (o tyle, o ile istniał wcześniej) się załamuje. Przywołajmy jeszcze raz Parandowskiego, proszę pozwolić na dłuższy cytat. Oto gimnazjum we Lwowie, ostatnie lata przed I wojną światową, rozpoczyna się nowy rok szkolny. Nauczyciele po raz pierwszy po wakacjach wchodzą do dobrze im znanego budynku i z radością konstatują, że nic się nie zmienił - podobnie, jak „odsunęliby ze zgorszeniem myśl, że należy coś zmienić w zakresie idei i faktów, z których składała się ich wiedza. Zbudowana, jak sam gmach, w XIX wieku, nie doznała od tej pory żadnych przeróbek, tak dalece wydawała się solidna i godna zaufania. Opierała się na ziemi, której bieg w przestworzach regulowały

15 J. Parandowski, Niebo w płomieniach, Warszawa 1976, s. 103.

16 „Modernity is not necessarily secularizing; it is necessarily pluralizing”, P.L. Berger, Secularization falsified, 〈http://www.firstthings.com/article/2008/02/002-secularization -falsified > (dostęp: 13 V 2015), (tekst wykładu, wygłoszonego w New School of Social Research 10 X 2007). 
niezłomne prawa mechaniki, a której powierzchnia zdradziła chyba wszystkie swe tajemnice podróżnikom, okrętom i kolejom; na kształt cementu spajała ją materia, zwarta i ścisła w swych niepodzielnych atomach, zamkniętych w tablicy pierwiastków Mendelejewa, jak anioły w niewzruszonych hierarchiach; panował w niej równy, spokojny ład, który z mgławic odwija systemy słoneczne i który pchnął kiedyś pierwszą komórkę w tor życia. Gmach zakładu w swej architekturze miał pewne podobieństwo do wiedzy wyznawanej w jego murach. Przejrzysty rozkład sal i korytarzy, bez mrocznych zakamarków, dobrze osadzona klatka schodowa, szeroka i jasna, całość w zwięzłym czworoboku, który wydawał się wyższy $\mathrm{i}$ bardziej monumentalny, niż był w istocie, pewien arystokratyzm w odosobnieniu poza sztachetami, [- - ] ślepe okna w dwóch rogach, zachodnim i wschodnim, skąd przychodzą najrychlej dokuczliwe przeciągi - czyż nie był to właściwy kształt dla ducha wypoczywającego wśród osiągniętych celów?..."17.

Ten lekko ironiczny opis służyć może za modelowe ujęcie dziewiętnastowiecznej umysłowości. „W swych niepodzielnych atomach, zamkniętych w tablicy pierwiastków Mendelejewa, jak anioły w niewzruszonych hierarchiach" - ta formułka wydaje mi się kluczowa. Jest analogia między racjonalizmem i dążeniem do budowy systemów nauki pozytywistycznej a racjonalizmem i dążeniem do budowy systemów w filozofii średniowiecza. Co za tym idzie, można bronić tezy, że w racjonalistycznej atmosferze XIX w. przy wszystkich konfliktach katolicyzm, ze swym racjonalizmem neoscholastycznej teologii, i antyklerykalizm, ze swym racjonalizmem nowoczesnego scjentyzmu, w dziwny sposób koegzystowały ze sobą. Teraz ta atmosfera legła w gruzach: łamie się racjonalizm zarówno nauki,jak i scholastyki. Młody człowiek - bohater powieści Parandowskiego - buntuje się przeciw religii i scholastyce, ale w pewien sposób jego bunt skierowany jest także przeciw atmosferze w gimnazjum, przeciw owemu „duchowi, wypoczywającemu wśród osiągniętych celów”. A atmosferę tę tworzyli przecież wszyscy nauczyciele, nie tylko prefekt - katecheta.

Kultura fin-de-siècle'u jest dla życia religijnego zarazem szansą i zagrożeniem: szansą, bo załamanie naiwnego pozytywizmu otwiera przed uczuciowością religijną nowe perspektywy. Ten nastrój tęsknoty za tajemnicą i metafizyką odczuwają bohaterowie Wieczorów nad Lemanem (1893) - apologetycznego dialogu pióra krakowskiego jezuity Mariana Morawskiego. (Sam Morawski był bardzo tradycyjnym katolikiem, ale umiał sugestywnie zarysować także te postawy, z którymi się nie identyfikował).Zagrożeniem, bo nastroje nowego irracjonalizmu mogą wieść w najróżniejsze strony, czę-

${ }^{17}$ J. Parandowski, op. cit., s. 118. 
sto wrogie dla religii - przykładem popularność Fryderyka Nietzschego w początku XX w.

Mamy więc z grubsza trzy nurty kulturowe: scjentystyczny pozytywizm, historyzm i irracjonalizm przełomu wieków (należałoby tu jeszcze dodać romantyzm, który w interesującej nas sferze oddziałuje podobnie jak wspomniany przed chwilą irracjonalizm). Odnoszę wrażenie, że z tych trzech nurtów scjentystyczny pozytywizm, choć najbardziej widoczny, był w sumie dla religii najmniej groźny, zresztą załamał się w latach dziewięćdziesiątych. Historyzm, który uderzał w samą ideę niezmienności i ponadczasowości chrześcijaństwa, i (neo-)romantyczny irracjonalizm, który dezawuował tradycję racjonalnej teologii, były z punktu widzenia chrześcijańskiej (niekoniecznie tylko katolickiej) prawowierności o wiele niebezpieczniejsze. Nie znaczy to, że nie można było wypracować intelektualnych rozwiązań, pozwalających na pogodzenie tych nurtów z rozmaitymi formami chrześcijańskiej ortodoksji - wymagało to jednak wysiłku filozoficznego, a także podjęcia pewnego ryzyka myślowego, do którego chrześcijanie nie zawsze byli zdolni.

c) Przemiany społeczne - intuicyjnie one wydają się najważniejsze, ale jeśli spojrzymy dokładniej, to rzecz staje się niejasna. Bo właściwie, jakie procesy społeczne powodują odejście od religii? I jakie procesy społeczne są najbardziej typowe dla dziewiętnastowiecznej Europy? Na pierwszy rzut oka wydaje się, że odpowiedź na oba te pytania jest jasna, a do tego jest to jedna i ta sama odpowiedź: wykorzenienie. Ale czy wykorzenienie naprawdę swoją wewnętrzną logiką prowadzi do odejścia od religii? ${ }^{18}$ Przecież, jeśli wolno pozwolić sobie na chwilę zdroworozsądkowego psychologizowania, można sobie wyobrazić mechanizm całkowicie przeciwny: człowiek wykorzeniony ze swego tradycyjnego środowiska może właśnie trzymać się kurczowo swojej religii jako jedynego elementu zrozumiałego i swojskiego w nowym i obcym świecie. Ludzie bywali ostatecznie wykorzeniani w każdej epoce - nie przez kapitalistyczne przemiany gospodarcze, ale przez wojny, klęski naturalne i inne plagi. Wzrost religijności, a nie jej spadek, bywał zwykle - i jest nadal - efektem takich klęsk.

Czym więc różni się kapitalistyczne wykorzenienie od tego powodowanego przez kataklizmy? Może zorganizowanym charakterem? Migrant ze wsi do miasta, zwłaszcza jeśli jest robotnikiem fabrycznym, zostaje porwany - proszę wybaczyć wyświechtane metafory - „w tryby” życia miejskiego, gdzie rytm nowego życia nie pozwala mu na kultywowanie dawnych zachowań. Dzieje się tak szczególnie wtedy, kiedy religijność tradycyjna

${ }^{18}$ Por. ważne i inspirujące rozważania na ten temat u Chadwicka, op. cit., s. 93 nn. 
nie była przeżywana wewnętrznie - a u większości ludzi chyba nie była lecz dyktowana sytuacją społeczną. Cytowany już Allport napisał, że „kryzysy życiowe mają tendencje tylko do intensyfikowania sposobu życia, który i tak już się rozwijał" ${ }^{19}$. Nawet jeśli nie jest to ogólna reguła, jest to z pewnością częste zjawisko. Kto migruje do miasta, przechodzi ze społeczności, w której chodzenie do kościoła było oczywistością, do takiej, gdzie znajduje możliwość odejścia od religii, i jeśli nie był z nią głębiej związany - odchodzi. W ten sposób wracamy do kwestii poruszonej już wcześniej: nowoczesność różnicuje, nie narzuca żadnej postawy w kwestii religii, lecz przedstawia różne możliwości, wprowadza (przez samo różnicowanie społecznych form gospodarowania, nawet jeśli zapomnimy na moment o dziewiętnastowiecznej ideologii liberalnej) najróżniejsze sposoby życia. W takiej sytuacji zaś osoby, które niegdyś chodziły do kościoła jedynie z konformizmu społecznego, z takiego samego konformizmu przestają doń chodzić: nowy konformizm zajmuje miejsce starego i społeczność laicyzuje się ${ }^{20}$ - a może właściwiej byłoby powiedzieć, że wcale się nie laicyzuje, że w istocie pozostawała potencjalnie laicka już przedtem?

Thomas Christopher Smout, analizując zmniejszające się znaczenie chrześcijaństwa w Szkocji w XIX i pierwszej połowie wieku XX, starał się wyjść poza ogólne spostrzeżenie wykorzenienia wynikającego z migracji i przedstawić nieco dokładniejsza analizę. Ukazuje on następujące czynniki: upadek wiary w piekło (niemożność literalnego rozumienia Biblii po Darwinie); rozwój społecznych funkcji państwa sprawiający, że społeczna działalność Kościoła jest mniej potrzebna; zastąpienie idei wspólnoty (dominującej na wsi) ideą klasy (stanowiącą podstawę tożsamości nowego proletariatu miejskiego); a wreszcie rozszerzanie się innych rozrywek niż nabożeństwa („the spread of other entertainment”). Podkreśla, że nie chodzi tu o nieumiejętność intelektualnego reagowania na przemiany: Kościół Szkocji dostosował się do nowych czasów, mówił mądre i ważne rzeczy, ale jego słowa „fell on deaf ears”. Zarazem postępowało powolne obniżanie się religijności, które przygotowuje szybki jej spadek od lat sześćdziesiątych XX w. Książka Smouta dochodzi aż do 1950 r. i niektóre procesy były w XIX w. ledwie widoczne, niemniej spojrzenie takie trafnie ujmuje pewne długofalowe tendencje $e^{21}$.

A do tego dodajmy jeszcze problemy „techniczne”: miasta, których tempo wzrostu w tak krótkim okresie nie miało paraleli w historii wcześ-

${ }^{19}$ G.W. Allport, op. cit., s. 135.

${ }^{20}$ R. Aubert [i in.], Historia Kościoła, t. 5: 1848 do czasów wspótczesnych, Warszawa 1985 (dalej: Historia Kościoła), s. 56.

${ }^{21}$ T.C. Smout, A Century of the Scottish People 1830-1950, London 1986, s. 181-208 (rozdział: „Churchgoing”). Oba cytaty ze s. 208. 
niejszej (a niewiele ma w późniejszej), nie nadążały z rozwojem swej infrastruktury - zbyt wolno powstawały nowe mieszkania, zbyt wolno rozwijały się kanalizacja, transport miejski, opieka medyczna, szkolnictwo. Dlaczego opieka religijna miałaby być tu wyjątkiem? Ogromne parafie wielkomiejskie, liczące dziesiątki, a czasem nawet ponad sto tysięcy wiernych, nie były łatwym terenem dla duszpasterstwa. Z drugiej strony, budowa kościoła w zlaicyzowanym środowisku stawać się mogła wyzwaniem, wyzwalającym energię organizacyjną - zbieranie funduszy, pozyskiwanie darczyńców itp. - która mogła stać się zalążkiem życia religijnego w nowych warunkach ${ }^{22}$.

Tworzenie się miejskiego proletariatu było jednym aspektem przemian społecznych; drugim, paralelnym, był rozkwit mieszczaństwa. O mało której grupie społecznej w historii napisano tak wiele powierzchownych, schematycznych sumarycznych sądów, zarzucając to i owo bądź rzadziej chwaląc. Wydaje się jednak niewątpliwe, że sukces mieszczaństwa jest jedną ze społecznych podstaw tego, co w poprzednim punkcie określiłem jako optymistyczny nastrój epoki. W tym sensie więc dostarczało ono bazy społecznej dla rozszerzania się postaw scjentystycznych, negujących sens i potrzebę religii. $Z$ drugiej strony wydaje się także niewątpliwe, że kultura mieszczańska jest w swoich korzeniach religijna, związana przede wszystkim (nie wyłącznie) z protestantyzmem. Która strona przeważała? Znowu, trudno orzec.

Wreszcie, przemiany modernizacyjne dotykały, w różnym stopniu, także i prowincję - wieś i miasteczko. Wieś europejska - nawet zacofana wieś galicyjska, nie mówiąc o nowocześniejszych regionach kontynentu - zostaje w ciągu XIX w. ostatecznie wprzęgnięta w światowy system kapitalistycznej gospodarki. Jest częścią szerokich powiązań rynkowych. To jednak nie przekłada się na sytuację społeczną i mentalną wewnątrz samej wsi i miasteczka. Prowincja jest częścią światowej gospodarki - ale w wielu prowincjonalnych regionach i miejscowościach ten niezaprzeczalny fakt jest słabo dostrzegany. Nic więc dziwnego, że w większości prowincjonalnych regionów w Europie przez cały XIX w. z punktu widzenia Kościołów wszystko wyglądało „w porządku”. Powieści Anthony'ego Trollope'a o anglikańskim duchowieństwie fikcyjnego miasta diecezjalnego Barchester („,bardziej godnego uwagi dla piękna swej katedry i starożytności swych zabytków niż dla jakichś sukcesów gospodarczych") i jego okolic, pisane

22 Jeden przykład: A. Auduc, Une difficile construction d'église en banlieue: l'exemple de Sainte-Marthe des Quatre Chemins à Pantin (1875-1897), „Revue d'histoire de l'Église de France" 85, 1999, 215, s. 291-314, 〈http://www.persee.fr/web/revues/home/prescript/ article/rhef_0300-9505_1999_num_85_215_1372〉(dostęp: 19 V 2015). 
w trzeciej ćwierci XIX w., ukazują świat stabilny i pogodny. Jego opisane z życzliwą ironią problemy koncentrują się wokół wydawania córek za mąż i starań o osiągnięcie kościelnych godności. Przemiany społeczne są w tym świecie niemal niewidoczne, choć - z perspektywy czasu widzimy to doskonale - nabrzmiewają pod powierzchnią. Pierwsza z powieści cyklu, The Warden (1855), przedstawia idealistycznego młodego człowieka, który oskarża kuratora pewnego kościelnego przytułku o przywłaszczanie sobie części funduszy przeznaczonych dla podopiecznych. Młody człowiek jest lekarzem w miejskim szpitalu i właśnie wrócił do rodzinnego miasta po studiach medycznych w Londynie. Widać tu ważne zjawisko: nie ma prowincji odizolowanej od wielkiego świata, bo istnieją jednostki, które przenoszą na peryferie procesy z centrum.

Analogiczny przykład, już nie z literatury pięknej: czeski badacz historii społecznej ukazał, jak na Morawach w pierwszych latach XX w. do małych miasteczek i wsi, zamieszkanych głównie przez katolicką ludność czeskojęzyczną, pozostających na uboczu procesów modernizacyjnych, przybywają idee antyklerykalne. Przybywają z zewnątrz, z Brna czy innych dużych miast; nie natrafiają na mocne poparcie lokalne i w zasadzie niczego nie zmieniają. Niby wszystko pozostaje jak było: młody radykał z powieści Trollope'a żeni się w końcu z córką kuratora, a antyklerykalny czeski nacjonalista, przemawiający na zebraniu w morawskim miasteczku, kiedy na dźwięk dzwonów jego słuchacze czynią znak krzyża - sam też musi się przeżegnać, bo wie, że inaczej straciłby wszelkie szanse na zaufanie publiczności ${ }^{23}$.

Jednak coś się zmienia: zarówno bohater The Warden, jak i opisani przez Lukaša Fasorę morawscy antyklerykałowie mogą liczyć na poparcie jakichś jednostek wśród małomiasteczkowej społeczności. Kiedy warunki się zmienią, kiedy przemiany społeczne dojdą i tutaj (a kiedyś przecież się to stanie, choć w większości przypadków już po dacie końcowej, którą przyjęliśmy dla tego szkicu) - wtedy grupa owych „odmieńców”, stojących poza tradycyjną strukturą lokalnego społeczeństwa i gotowych do poparcia przychodzących z zewnątrz impulsów, może się wydatnie zwiększyć, a w efekcie może (choć nie musi) się okazać, że tradycyjna religijność prowincji stoi na kruchych nogach i załamuje się stosunkowo szybko.

Przemiany społeczne i intelektualne groziły wyznaniom chrześcijańskim utratą mas i utratą elit. Które z tych zagrożeń było w XIX w. bardziej bezpośrednie? Chadwick w wielokrotnie cytowanej tutaj książce podkreśla

${ }^{23}$ L. Fasora, Sociální souvislosti procesu sekularizace $v$ málych komunitách $v$ letech 1890-1913, w: Sekularizace českých zemí v letech 1848-1914, wyd. idem, J. Hanuš, J. Malír, Brno 2007, s. 35-48. 
rzecz z polskiej perspektywy niemal niebywałą: w Anglii wiktoriańskiej odchodziły od chrześcijaństwa raczej masy (miejskie masy, ma się rozumieć) niż elity. Robotnik, który chodziłby do kościoła (anglikańskiego) albo do kaplicy (metodystycznej), narażał się, jak pisze Chadwick, na kpiny swych kolegów i podejrzenie, że chce się ukazać jako ktoś wyższy społecznie od nich, ktoś, kto małpuje zachowanie klas wyższych ${ }^{24}$.

Nie potrafię powiedzieć, $w$ jakim stopniu ten mechanizm działał w innych środowiskach i w innych częściach kontynentu. Wydaje się, że angielska klasa robotnicza była świadoma swej zbiorowej odrębności w stopniu większym niż robotnicy z kontynentalnej Europy (przypomnijmy, co pisał Smout: identyfikacja z klasą wyparła identyfikację ze wspólnotą). Wynikało to - jak pokazał kiedyś Edward P. Thompson w swej doskonałej książce The Making of the English Working Class (1965) - nie z oddziaływania marksizmu, na który angielscy robotnicy byli bardzo odporni, lecz z siły tradycji angielskiego radykalizmu, którego źródeł szukać trzeba w XVII w., w epoce angielskiej rewolucji i wojny domowej. Angielscy robotnicy, zakorzenieni w tradycji swobód przysługujących im jako „Free-born Englishmen", zakładali stowarzyszenia, występowali z postulatami dotyczącymi przemian społecznych i politycznych - a chociaż ten aktywizm miał korzenie religijne, to w XIX w. stawał się coraz bardziej świecki, kiedy zarówno Kościół anglikański, jak i radykalny niegdyś ruch metodystyczny postrzegane były coraz bardziej jako część tradycyjnego establishmentu.

Sytuacja na kontynencie europejskim była chyba jednak inna - robotnicy, nawet wychowywani przez socjaldemokrację robotnicy w Cesarstwie Niemieckim w ostatniej ćwierci XIX w., byli mniej świadomi klasowej wspólnoty, bardziej zależni od swych dawnych wiejskich wspólnot (bo industrializacja dokonywała się później niż w Wielkiej Brytanii, a więc więzy nie zdążyły się jeszcze całkowicie zatrzeć), a zresztą w krajach mniej zindustrializowanych niż Wielka Brytania stanowili mniejszy procent społeczeństwa. Robotnicy warszawscy przełomu XIX i XX w. zachowali nie tylko samą religię, ale także związane z nią tradycyjne obrzędy ludowe, które przynieśli do miasta ze wsi. Na podstawie wspomnień i innych relacji można przyjąć, że Kościół stanowił dla nich rodzaj odskoczni od ciężarów życia codziennego ${ }^{25}$. Intuicyjnie skłonny byłbym sądzić, że w większości Europy niewiara w XIX w. jest przede wszystkim sprawą elit, a także stosunkowo niewielkiej części ogółu społeczeństwa.

${ }^{24}$ O. Chadwick, op. cit., s. 102.

${ }^{25}$ A. Żarnowska, Robotnicy Warszawy na przełomie XIX $i$ XX wieku, Warszawa 1985, s. $178-180$. 
Jedynie marginalnie wspomnieć możemy o specyfice Stanów Zjednoczonych, gdzie budowa nowoczesnego społeczeństwa kapitalistycznego nie oznaczała - co zauważył już w latach trzydziestych XIX w. Alexis de Tocqueville - upadku religijności, a instytucje religijne, zdecentralizowane i różnorodne, same stanowiły element amerykańskiej demokracji, opierającej się na sile stowarzyszeń i lokalnych instytucji.

d) Kolejnym punktem wartym rozważenia są przemiany polityczne mianowicie tworzenie sięnowoczesnego państwa. Wiele prac socjologicznych poświęconych problematyce sekularyzacji koncentruje się na punktach b) i c) wymienionych powyżej. Również doskonała książka Chadwicka, nieoceniony przewodnik po problematyce niniejszego szkicu, pisana z brytyjskiej perspektywy, kwestię wpływu polityki państwowej na życie religijne w zasadzie pomija. A przecież nawet najbardziej pobieżne spojrzenie na wiek XIX ukazuje, jak ogromne znaczenie miał konflikt między tworzącym się nowoczesnym państwem a Kościołem (chodzi tu nie jedynie, ale głównie o Kościół katolicki, który znajdował się w sytuacji szczególnie konfliktowej ze względu na swoją powszechność, a co za tym idzie - ponadnarodową strukturę). Niemiecki Kulturkampf, który dał uogólnioną i po dziś dzień używaną nazwę (obecnie częściej w wersji angielskiej jako culture wars), jest tylko najbardziej znanym przykładem zjawiska istniejącego przynajmniej od czasów oświecenia. Przynajmniej - bo można przecież twierdzić, że napięcie między władzą świecką a duchowną jest wbudowane w świat zachodniego chrześcijaństwa i że ten spór, kulminujący w średniowiecznej walce cesarstwa z papiestwem, przesądził o rozwoju idei wolności w Europie, skoro żadna ze stron nie zdołała uzyskać zwycięstwa, ale każda była wystarczająco silna, by zapobiec zwycięstwu drugiej (tak przynajmniej twierdził w XIX w. lord Acton, przenosząc brytyjską konstytucyjną teorię checks and balances na rozwój życia politycznego całego kontynentu). Wczesnonowożytne spory wokół gallikanizmu we Francji również można zaliczyć do tego samego nurtu. Jeśli jednak odłożymy na bok te antecedencje, to absolutyzm oświecony otwiera tu nową epokę - a szczególnie polityka określana mianem józefinizmu. Dawne pola sporu obracały się przede wszystkim wokół monarszej zwierzchności nad publiczną działalnością Kościoła: kwestia wpływów monarchy na nominacje biskupów, kontroli ich kontaktów ze Stolicą Apostolską oraz sprawa tzw. placetum regium, tzn. monarszej kontroli nad publikacją w danym państwie bulli i innych dokumentów papieskich. Teraz jednak doszły do tej listy sprawy o wiele szersze i w sumie o wiele trudniejsze do kompromisowego rozwiązania. Była to kwestia kontroli nad szkołą oraz stopniowo - także i nad ruchem ludności, w tym przede wszystkim nad warunkami zwierania małżeństw, a stopniowo także i udzielania rozwo- 
dów. Do tego dochodziła jeszcze sprawa użyteczności społecznej duchowieństwa, którą „wiek świateł” uważał za centralne kryterium racji istnienia jakiejkolwiek instytucji. Praktycznym efektem tej ostatniej kwestii było zamykanie klasztorów, zwłaszcza kontemplacyjnych, uważanych za „nieużyteczne”, oraz wymaganie, by Kościół na poziomie parafialnym przejął część zadań, w zasadzie należących do sfery zainteresowań administracji państwowej, zbyt słabo jeszcze rozwiniętej, aby im podołać. Chodziło tu, obok wspomnianej już rejestracji ruchu ludności, o ogłaszanie rozporządzeń władz państwowych, a także o zbieranie danych statystycznych (w oświeceniowym, a więc szerszym niż dzisiejsze, znaczeniu tego słowa) o parafii.

Wręcz modelowym przykładem takiego sporu kompetencyjnego może być konflikt między Kościołem a władzami państwowymi w Księstwie Warszawskim i w pierwszych latach konstytucyjnego Królestwa Polskiego. Nałożono na proboszczów obowiązek odczytywania z ambony rozporządzeń urzędowych, spierano się o prowadzenie ksiąg stanu cywilnego (wielki spór o śluby cywilne w Księstwie Warszawskim) i o wpływ władz na obsadzanie biskupstw.Dekret królewski z 6/18 marca 1817 r. „O stopniu dozoru i opieki rządu nad duchowieństwem" (samo sformułowanie tytułu jest charakterystyczne) pozwalał wnosić skargi na proboszczów do ministra wyznań religijnych i oświecenia publicznego ${ }^{26}$. Minister ów, Stanisław Kostka Potocki, jeden z głównych przedstawicieli polskiego oświecenia, musiał, jak wiadomo, podać się do dymisji w efekcie omawianego konfliktu.

W ciągu całego XIX w. konflikty takie wybuchały praktycznie w każdym kraju z silną obecnością katolików. Były one rozmaitej natury i - co ważne i ciekawe - mogły być wyrazem najróżniejszych postaw i ideologii. Po pierwsze były - to oczywiste - wyrazem antyklerykalnego liberaliz$\mathrm{mu}$, po drugie - protestanckiego uprzedzenia antykatolickiego, po trzecie wreszcie - mogły być wyrazem po prostu politycznego tradycjonalizmu, dążenia tradycyjnych elit do utrzymania kontroli nad społeczeństwem. W ten sposób jeden z najwybitniejszych znawców dziejów ustroju Węgier dziewiętnastowiecznych, László Péter, interpretował tak zwany węgierski Kulturkampf z lat dziewięćdziesiątych. Według niego walka rządzących Węgrami liberałów z Kościołem wpisuje się w pewien szerszy schemat rozwoju Węgier po 1867 r.: liberalno-konstytucyjna forma staje się instrumentem tradycyjnych szlacheckich elit, które za jej pomocą blokują demokratyzację kraju, torpedując wszelkie niekontrolowane przez państwo

${ }^{26}$ A. Barańska, Między Warszawa, Petersburgiem i Rzymem. Kościół a państwo $w$ dobie Królestwa Polskiego, Lublin 2008, s. 470-471. 
inicjatywy, w tym i działalność Kościoła katolickiego ${ }^{27}$. Elementy takiego modelu można spotkać w wielu przypadkach i zwykle łączyły się one z pozostałymi wyróżnionymi powyżej motywacjami. W umyśle Ottona von Bismarcka ewidentnie łączyło się tradycyjne uprzedzenie protestanckie z konserwatywnym przekonaniem, że Kościół katolicki zagraża hierarchicznemu porządkowi przez swoją kontrolę fanatycznie religijnej masy wyznawców (Bismarck pisał o „demokratischer Jesuitismus" ${ }^{28}$ swoich katolickich przeciwników). U niemieckich narodowych liberałów, takich jak choćby Heinrich von Sybel, idee etatystyczne wychodziły z nieco innych źródeł niż u Bismarcka - z przekonania, które genetycznie odnieść można wstecz aż do myśli Thomasa Hobbesa, że nowoczesne państwo, skupiające w sobie pełną suwerenność, jest warunkiem wolności jednostki, bo tylko ono wyzwolić może jednostkę z pęt, w których dotychczas pozostawała. Klasyczny podręcznik nauk prawno-politycznych wybitnego liberalnego prawnika szwajcarskiego Kaspra Davida Bluntschlego daje doskonały przykład takiego liberalno-etatystycznego (i wyraźnie mizoginicznego) sposobu myślenia. Elementy demonizacji katolicyzmu są u Sybla i wielu innych niemieckich „narodowych liberałów” niemal takie same jak u konserwatysty Bismarcka ${ }^{29}$.

Nasuwa się melancholijna myśl, że przedstawiony powyżej konflikt był w pewnym sensie nieuchronny, a w każdym razie (nawet przy utopijnym założeniu najlepszej woli po obu stronach) bardzo trudny do uniknięcia czy rozwiązania. Nowoczesne państwo brało pod swą kontrolę coraz to nowe dziedziny życia: nie z zachłanności, żądzy władzy czy w ogóle z wolnego wyboru, ale ze względu na, jak powiedziałby Monteskiusz, „,konieczne stosunki, wynikajacce z natury rzeczy”. Przemiany techniczne i społeczne (a także ideowe, ale przy genezie tego akurat zjawiska ich rola nie była chyba centralna) dają początek coraz to nowym sferom życia, które po prostu trzeba kontrolować. Najprostszy zdroworozsądkowy przykład to choćby kodeks drogowy, który nie jest niezbędny (może z wyjątkiem rudymentów), dopóki zagęszczenie pojazdów i ich średnia prędkość nie przekroczy pewnego punktu krytycznego - potem zaś nie można bez niego funkcjonować. Jako norma,

${ }^{27}$ L. Péter, Church-State Relations and Civil Society in Hungary. A Historical Perspective, w: idem, Hungary's Long Nineteenth Century. Constitutional and Democratic Traditions in a European Perspective. Collected Studies, oprac. M. Lojkó, Leiden-Boston 2012, s. 405-437; idem, Hungarian Liberals and Church-State Relations, w: Hungary and European Civilization, red. G. Ránki, Budapest 1989, s. 79-138.

${ }^{28}$ O. von Bismarck, Gedanken und Erinnerungen, t. 2, Berlin-Stuttgart 1922, s. 163.

${ }^{29}$ M.B. Gross, Kulturkampf and Unification: German Liberalism and the War Against the Jesuits, „Central European History” 30, 1997, 4, s. 545-566, 〈http://www.jstor.org/ stable/4546748> (dostęp: 23 III 2015). 
której istotą nie jest konkretna treść, tylko jej powszechne przestrzeganie (nie jest ważne, czy jeździmy po lewej, czy po prawej stronie drogi, ważne jest, żebyśmy wszyscy jeździli po tej samej) - musi być narzucony przez władze państwowe.

Przechodząc do kwestii bliższych tematyce niniejszego szkicu - coraz bardziej skomplikowane życie gospodarcze pociąga za sobą konieczność coraz bardziej skomplikowanych systemów podatkowych (wraz z systemami kontroli), a to implikuje konieczność nadzoru przez państwo przemian demograficznych; małżeństwo staje się domeną władzy świeckiej, a nie tylko duchownej. Rozwój instytucji życia społecznego i gospodarczego pociąga za sobą konieczność pewnego poziomu wykształcenia mas jako warunku samego funkcjonowania w społeczeństwie - a to sprawia, że szkoła staje się coraz ważniejszą instytucją społeczną i obiektem sporu między Kościołem (Kościołami) a państwem. Nikt tego nie zaplanował, nie ma żadnego wszechogarniającego spisku masońskiego dla wyparcia Kościoła z życia publicznego, podobnie jak z drugiej strony nie ma żadnego spisku jezuicko-klerykalnego dla powstrzymania pochodu przemian. Ale istnieje po obu stronach wrażenie, że zła wola z drugiej strony generuje konflikt, podczas gdy ona najwyżej wzmacnia konflikt tworzący się poza świadomością jego uczestników.

Jednak ów obraz ostrego konfliktu zostanie stonowany, jeśli weźmiemy pod uwagę dwa istotne czynniki łagodzące. Po pierwsze: państwo dziewiętnastowieczne, czyli tworzące się nowoczesne państwo biurokratyczne, oscylując w swym stosunku do Kościołów i religii między wrogością, tolerancją a współpracą, nie może w żaden sposób się obyć bez elementów legitymizacji religijnej (możliwym wyjątkiem jest tu III Republika Francuska). Anna Barańska, charakteryzując postawę ministra S.K. Potockiego, pisze, że nie chciał on zniszczenia Kościoła, lecz jego „etatyzacji” 30 . To trafne sformułowanie oddaje istotę sprawy. Doskonałym przykładem owej chwiejnej równowagi, współpracy połączonej z konfliktem, którego jednak żadna ze stron nie chce zbytnio eskalować, bo zbyt wiele ma w sumie do stracenia, jest drugie cesarstwo francuskie, jako symbol zaś służyć może kult św. Napoleona ${ }^{31}-$ nieco zabawne połączenie interesów ołtarza i tronu. Myślę, że taki właśnie model chwiejnej równowagi był typowy dla dziewiętnastowiecznych stosunków państwo-Kościół, nie zaś model „mocnej” laickości państwa, jak w przypadku III Republiki Francuskiej po ustawach z 1905 r.

${ }^{30}$ A. Barańska, op. cit., s. 489.

${ }^{31}$ Bardzo dobre studium: S. Hazareesingh, Religion and Politics in the Saint-Napoleon Festivity (1852-1870): Anti-Clericalism, Local Patriotism and Modernity, „The English Historical Review" 119, 2004, 482 (June), s. 614-649. 
Po drugie: byłoby jednostronne, gdybyśmy ową tendencję do rozszerzania zasięgu władzy państwowej widzieli wyłącznie w kategoriach ataku na przywileje Kościoła. Szczególnie w XVIII w. wiele pomysłów oświeconych reformatorów znajdowało poparcie u reformistycznych teologów katolickich. W Niemczech korzystną dla józefińskich reform sytuację stwarzał nurt zwany febronianizmem (od pseudonimu Febronius, pod którym biskup pomocniczy Trewiru Johannes von Hontheim opublikował swoją pracę o granicach władzy papieża nad biskupami). Głosił on potrzebę większej niezależności biskupów od Rzymu, i z tej perspektywy koncepcje józefińskie mogły wydawać się sprzyjające, bo osłabiając zwierzchnictwo papiestwa nad Kościołem w państwach habsburskich, tym samym wzmacniały pozycję poszczególnych biskupów (choć z drugiej strony stawiały ich bez rzymskiej ochrony vis-à-vis silnej władzy państwowej). Liczne działania Józefa II na rzecz reformy zakonów, uproszczenia liturgii, skierowania zainteresowania Kościoła w kierunku praktycznego życia wiernych - to wszystko były problemy, które zajmowały oświeconych teologów i hierarchów kościelnych na ziemiach niemieckojęzycznych w drugiej połowie wieku XVIII. Józefinizm był dziełem teologów, a ,za każdym rozporządzeniem tego cesarza stał jako inspirator jakiś teolog lub kanonista" - pisze francuski historyk Kościoła Louis J. Rogier ${ }^{32}$. Taki pogląd na józefinizm jako w gruncie rzeczy formę oświeconego katolicyzmu z pewnością jest jednostronny - ale jako jeden z punktów widzenia może być dopuszczalny i ujawnia coś istotnego. Rewolucja francuska zaostrzyła przeciwieństwa i utrudniła pozycję katolickich zwolenników reformy, ale nie zlikwidowała takich postaw, widocznych m.in. w państwach niemieckich w pierwszej połowie XIX w.

A jeśli tak, jeśli dążenie nowoczesnego państwa do „wyparcia” katolicyzmu z niektórych jego pozycji nie zawsze nosiło wrogi wobec chrześcijaństwa charakter, to niczym dziwnym nie będzie konstatacja, że i jego efektów nie da się jednoznacznie zakwalifikować. Wydaje się, że działał podobny mechanizm co w przypadku przemian społecznych, przedstawionych w punkcie poprzednim. Z jednej strony państwo ułatwiało odejście od religijności, bo stwarzało sytuację, w której religijność nie była już jedyną społecznie akceptowalną opcją (stwierdzenia tego nie zmienia fakt, że w większości wypadków państwo walczące z Kościołem nie starało się podważać religijności masowej - fakt konfliktu trudno było ukryć i sam ten fakt sprawiał, że religijność przestawała być czymś oczywistym). Niezależnie od „konfliktowości” jako takiej samo zjawisko emancypacji insty-

${ }^{32}$ L.J. Rogier, G. de Berthier de Sauvigny, J. Hajjar, Historia Kościoła, t. 4: 1715-1848, Warszawa 1987 (dalej: Historia Kościoła) (oryg. franc. 1966), s. 102. 
tucji państwowych spod wpływów Kościołów, nawet jeśli dokonywało się pokojowo, było dla odchodzenia od religijności zjawiskiem bardzo ważnym. Dzięki tej emancypacji zmniejszała się bowiem sfera koniecznych kontaktów z instytucjami religijnymi, co oczywiście nie wpływało na postawy ludzi świadomie religijnych, ale dla ludzi potencjalnie obojętnych religijnie otwierała się możliwość życia nawet nie wbrew instytucjom kościelnym, lecz poza nimi (znowu owa „zmiana konformizmów”, o której była już mowa).

Z drugiej strony zaś uwolnienie się od brzemienia bezpośrednich funkcji administracyjnych na dłuższą metę sprzyjało wzrostowi autorytetu moralnego Kościoła katolickiego i ocaliło go przed wstrząsami, jakim podlegały instytucje świeckie w XIX i XX w., a także przed możliwą kompromitacją, jaka z dużym prawdopodobieństwem nastąpiłaby w wyniku nadużyć i nieudolności administracyjnej. Wyważyć wzajemnego znaczenia obu tych tendencji niepodobna.

Thomas Nipperdey zwraca uwagę, że owa budowa nowoczesnego państwa miała pewien pośredni wpływ na wewnętrzną strukturę Kościoła katolickiego: uległ on przynajmniej częściowej „defeudalizacji”. Utracił część przynajmniej swoich majątków, rozmaite instytucje kościelne zostały mniej lub bardziej uzależnione od państwa, zmniejszyły się dochody i polityczne znaczenie biskupów. Wszystko to ułatwiło bezprecedensową centralizację Kościoła pod hasłami ultramontańskimi, która dokonała się - jak będzie mowa - za pontyfikatu Piusa IX ${ }^{33}$.

Jeszcze jedna kwestia dotycząca omówionych wyżej czterech punktów przyciągnąć musi naszą uwagę: jeśli religijność eroduje w wyniku przemian (społecznych, intelektualnych albo politycznych), to co zajmuje jej miejsce? Może inna religijność? Włodzimierz Pawluczuk badał działalność protestanckich grup religijnych w białoruskich wsiach okolic Białegostoku w okresie międzywojennym i ich popularność analizował właśnie w kontekście przemian, którym podlega - jak to ujmuje tytuł jego książki - „światopogląd jednostki w warunkach rozpadu społeczności tradycyjnej”. W XIX w. częściej jednak - tak się przynajmniej wydaje - miejsce religii zajmują nowe ideologie polityczne. Nacjonalizm i socjalizm są wśród nich pewnie najważniejsze. Nie będziemy tu wchodzić w ważny i szeroki problem świeckich religii. Czy marksizm można uznać za parareligię? Czy nacjonalizm nie jest po prostu zeświecczeniem chrześcijaństwa? Dla praktycznych potrzeb tego szkicu załóżmy (nie rozstrzygając samej kwestii), że religia odnosi się do jakiejś rzeczywistości pozaziemskiej, przyjmowanej za pewnik przez jej wyznawców. Wystarczy

${ }^{33}$ T. Nipperdey, Deutsche Geschichte 1800-1866, München 1998, s. 407. 
więc tylko przypomnieć, że nowe ideologie przejmują i przetwarzają niektóre elementy chrześcijaństwa: wielokrotnie pisano o podobieństwie między marksistowską filozofią dziejów a żydowską i chrześcijańską eschatologią, wielokrotnie zwracano też uwagę, jak wiele język i obrzędowość nacjonalistyczna zapożycza od chrześcijańskiego języka i obrzędowości. Przynajmniej w pewnym stopniu obie te ideologie, nie będąc w sensie ścisłym religiami, funkcjonalnie zajmują miejsce religii w światopoglądach jednostek.

Zarazem nacjonalizm i socjalizm nie rezygnują ze wsparcia tradycyjnych religii. Jest świadectwem siły dziewiętnastowiecznego chrześcijaństwa, że zarówno idee narodowe, jak i socjalistyczne wchodzą w taką czy inną symbiozę z wyselekcjonowanymi i zreinterpretowanymi ideami chrześcijaństwa. O tym, jak proces ten wyglądał od strony Kościoła katolickiego, będzie mowa w punkcie następnym; tutaj jedynie chciałbym zwrócić uwagę, że nie tylko istniejące władze państwowe, ale także ruchy „antyestablishmentowe", narodowe i społeczne, wykorzystywały chrześcijańską symbolikę, a czasem podejmowały głębszą refleksję o wzajemnym stosunku swoich ideałów i ideałów chrześcijaństwa.

\section{Kościół katolicki reaguje na nowoczesność}

Do tej pory mówiliśmy o procesach w społeczeństwie jako całości, teraz przyjrzyjmy się reakcji na nie ze strony samych chrześcijan (skoncentrujemy się na Kościele katolickim). Ogólny podręcznikowy schemat wyglądałby zapewne następująco: Kościół, po epoce barokowo-kontrreformacyjnych triumfów, został wzięty zupełnie z zaskoczenia przez nowe idee oświeceniowe i nie potrafił zdobyć się na nic innego poza powtarzaniem swego stanowiska sprzeciwu. Taka postawa usztywniła się jeszcze w efekcie rewolucji francuskiej, postrzeganej przez ludzi Kościoła jako naturalne następstwo oświecenia, a jej kulminacją był pontyfikat Piusa IX (18461878) i I Sobór Watykański, z jego emfatycznym potwierdzeniem tradycyjnej nauki w postaci dogmatu o papieskiej nieomylności. Dopiero podczas pontyfikatu Leona XIII Kościół zaczął reagować na problemy wywołane przez przemiany społeczne i ideowe poprzednich stu lat (encyklika Rerum novarum, 1891). Od tego czasu, choć z wahaniami (walka z modernizmem za pontyfikatu Piusa X), Kościół stara się tak czy inaczej odpowiadać na zmieniające się wyzwania nowych epok - aż po nasze czasy.

Ten obraz jest jednak zbyt ogólnikowy. Przede wszystkim nie uwzględnia on olbrzymiego dorobku katolickiego oświecenia ${ }^{34}$. Jako spójna pro-

${ }^{34}$ Richard Butterwick-Pawlikowski (Między oświeceniem a katolicyzmem, czyli o kato- 
pozycja światopoglądowa załamało się ono wprawdzie wraz z okrucieństwami rewolucji francuskiej. Jednak jego idee nie zanikły, pozostały długo w ciągu XIX w., przede wszystkim w krajach niemieckich. W pewien sposób dały one początek różnym nurtom dążącym w XIX, i w początkach XX w. do zreformowania Kościoła - katolicyzmowi liberalnemu i ruchowi chrześcijańsko-społecznemu, a także, w nieco bardziej okrężny sposób, katolickiemu modernizmowi. To ostatnie było możliwe dlatego, że w myśli oświecenia katolickiego już przed 1789 r. wzmacniały się idee, pozostające pod wpływem protestanckiego pietyzmu i mody na sentymentalizm, dające prymat uczuciu religijnemu kosztem „zimnego” rozumowania. Idee te wzmocniły się jeszcze w pierwszych dekadach XIX w. pod wpływem tryumfującego romantyzmu.

Po drugie obraz ten nie uwzględnia tendencji do zmiany i prób reform, jakie istniały w Kościele przez cały omawiany okres. Świat jest bardziej skomplikowany, niż wynikałoby to z podręcznikowego obrazu.

Po trzecie wreszcie istnieje w historiografii tendencja do rewizji oceny postaw zwykle uznawanych za bezrefleksyjnie tradycyjne - tendencja, aby widzieć politykę Piusa IX nie jako kurczowe trzymanie się starych form, tylko właśnie jako politykę swoistej - bardzo swoistej - modernizacji Kościoła. Kiedy Olaf Blaschke pisał swój klasyczny już dzisiaj tekst o XIX w.jako „drugiej epoce konfesjonalizacji” ${ }^{35}$, miał na myśli w ogólniejszym sensie siłę religii w XIX w., a w szczególniejszym - rolę „konfesji”, czyli wyznania, które ponownie, jak w wieku XVII, coraz bardziej stawało się wraz z demokratyzacją wyznacznikiem postaw w kwestiach politycznych i kulturowych. Można jednak również mówić o dziewiętnastowiecznej konfesjonalizacji, nawiązując do klasycznych ujęć problemu konfesjonalizacji wczesnonowożytnej - jako polityki centralizacji i „ujednolicenia” polityczno-religijnego. W tym rozumieniu polityka Piusa IX zmierzająca do „usztywnienia” katolicyzmu zarówno w sensie doktrynalnym, jak i administracyjnym byłaby właśnie przykładem nowej konfesjonalizacji. Ultramontanizm zaś nie byłby - jak się na ogół przyjmuje - ruchem tradycjonalistycznym, ale częścią owej centralizującej modernizacji Kościoła, a więc jakby kościelnym odpowiednikiem budowy scentralizowanego państwa świeckiego. Interpretacja ta nie jest całkiem przekonywająca, ale warta namysłu.

lickim oświeceniu i oświeconym katolicyzmie, „Wiek Oświecenia” 30, 2014, s. 11-53) daje przegląd najnowszych stanowisk historiografii oraz wysuwa interesującą propozycję koncepcyjnego rozróżnienia między „katolickim oświeceniem” a „oświeconym katolicyzmem".

${ }^{35}$ O. Blaschke, Das 19. Jahrhundert: Ein Zweites Konfessionelles Zeitalter?, „Geschichte und Gesellschaft" 26, 2000, 1, s. 38-65, 〈http://www.jstor.org/stable/40185968〉(dostęp: 14 XI 2014). 
W bardzo ciekawym tekście Christopher Clark analizuje odrodzenie religijne katolicyzmu w XIX w. w kategoriach modernizacji ${ }^{36}$. Polemizuje z tymi badaczami, którzy oddzielają nowoczesne środki od nienowoczesnych celów i w całej historii dziewiętnastowiecznego Kościoła widzą co najwyżej zwalczanie nowoczesności nowoczesnymi metodami. Liberalna nowoczesność nie jest jedyną jej odmianą - pisze Clark. W zasadzie takim poglądom można tylko przyklasnąć. Klasyczny już tekst z 2000 r. Shmula N. Eisenstadta Multiple modernities dostarcza tutaj kategorii interpretacyjnych, zwracając uwagę na wielość form, w jakich nowoczesność może się realizować - dzisiejszy fundamentalizm muzułmański nie jest mniej nowoczesny niż liberalna demokracja. Jednak traktując Kościół jako „nowoczesnego" aktora na scenie dziewiętnastowiecznego świata, podejście takie jak przedstawione powyżej może zacierać różnicę między pontyfikatem Piusa IX i jego poprzedników a czasami jego następcy, różnicę, która była widoczna dla współczesnych i której nie należy zagubić. Sądzę więc, że przedstawionego na wstępie niniejszego punktu schematycznego obrazu nie należy całkiem odrzucać. Rzeczywiście, wydaje się widoczne, że do lat siedemdziesiątych XIX w. Kościół zachowuje się wobec nowoczesności raczej bezradnie, a w każdym razie bezradniej niż w okresie późniejszym.

Tę różnicę można ująć następująco. Do końca pontyfikatu Piusa IX Kościół używa w coraz większym stopniu środków nowoczesnych, jednak całościowa katolicka wizja świata - ze wszystkimi zastrzeżeniami, o których wyżej - jest wroga nowoczesności (cokolwiek miałoby to oznaczać). Jeden z historyków napisał, że Pius IX, ciągle krytykując świat dzisiejszy, był jednak bardziej nowoczesnym przywódcą niż sam by mógł przypuszczać („he was more a modern leader than he knew”) ${ }^{37}$. To sformułowanie dobrze oddaje rolę nowoczesnych elementów w polityce kościelnej tamtego czasu. Jest ich wiele, lecz rządzi nimi strach przed światem. Nie widać powodów, by odrzucić pogląd powszechny w dawniejszej historiografii, że „mimo wszystko jednak katolicyzm XIX wieku ma charakter konserwatywny i zajmuje w stosunku do nowych prądów stanowisko obronne"38.

Natomiast od czasów Leona XIII owe elementy nowoczesne są bardziej skoordynowane, włączane w jedną wspólną dla całego Kościoła politykę papiestwa - politykę, której celem nie jest już zwalczanie no-

${ }^{36}$ Ch. Clark, The New Catholicism and the European Culture Wars, w: Culture Wars. Secular-Catholic Conflict in Nineteenth-Century Europe, red. idem, W. Kaiser, Cambridge 2003, s. $11-46$, cyt. s. 45.

${ }^{37}$ M.R. O'Connell, Ultramontanism and Dupanloup: The Compromise of 1865, , Church History” 53, 1984, 2 (Jun.), s. 200-217, tu s. 204, 〈http://www.jstor.org/stable/3165356〉 (dostęp: 15 VI 2015).

${ }^{38}$ K. Górski, Zarys dziejów duchowości w Polsce, Kraków 1986, s. 274. 
woczesności jako takiej, ale tworzenie jej alternatywnego modelu. Alternatywnego wobec nowoczesności oświeceniowo-liberalno-laickiej. Kościół w drugiej połowie XIX i w pierwszej połowie XX w. unowocześnia się przez przejęcie nowoczesnych instytucji, technik oddziaływania i metod organizacyjnych - i zwrócenia ich przeciw głównemu dotychczas nurtowi nowoczesności. Leon XIII, jak wiadomo, zachęcił katolików, aby nie bojkotowali instytucji politycznych, lecz tworzyli własne partie, aby włączali się w życie polityczne i wykorzystywali je na swoją korzyść. Dążył do załagodzenia sporu z Bismarckiem i Niemcami. Przez encyklikę Rerum novarum usankcjonował lokalne formy społecznego zaangażowania ludzi Kościoła i stworzył podstawy pod nowoczesną katolicka naukę społeczną i praktykę opartą na tej nauce. Encyklika Aeterni Patris, proklamująca filozofię tomistyczną oficjalną filozofią Kościoła, ma podwójne oblicze. Można zasadnie twierdzić, że na dłuższą metę utrudniając rozwój innych niż tomistyczna dróg rozwoju myśli katolickiej, uniemożliwiała tym samym owocny dia$\log$ - a nawet sensowną polemikę - z nowoczesną nauką i większością nowych nurtów filozoficznych. Z drugiej jednak strony na krótszą metę miało dla Kościoła pozytywne skutki już samo to, że po często konstatowanym okresie upadku w pierwszej połowie XIX w. w ogóle odrodziła się jakakolwiek myśl teologiczna - już mniejsza o jej kierunek ${ }^{39}$.Zasługi Leona XIII dla otwarcia katolicyzmu na problemy nowoczesnego świata są niepodważalne, wzbudziły zresztą sprzeciw wielu ówczesnych konserwatystów, a „w niektórych klasztorach modlono się o to, by Bóg jak najrychlej uwolnił Kościół od tego "papieża-masona»" ${ }^{40}$.

Otwarcie to miało swe granice. O niektórych będzie mowa dalej, tutaj zaś chodzi mi o jedną kwestię od razu zauważalną dla każdego, kto porówna dzieje Kościoła dziewiętnastowiecznego z epokami wcześniejszymi. Kiedy mianowicie patrzymy na olbrzymie przemiany umysłowe w dziewiętnastowiecznej Europie, a szczególnie w pierwszej połowie stulecia, wtedy uderzyć nas musi, że „cały ten ogromny ferment [--] rozwija się na marginesie Kościoła katolickiego" ". Myślę, że jest to pierwsza epoka w dziejach chrześcijaństwa od czasów edyktu mediolańskiego, o której można coś takiego powiedzieć. Kościół, może po raz pierwszy w całej swej historii, broni się, reaguje na zewnętrzne idee, nie będąc w stanie samemu wyznaczyć pola sporu. Broni się zaś dość bezradnie, jakby zapominając o swej wielkiej i różnorodnej tradycji teologicznej, która przez stulecia pozwalała mu

${ }^{39}$ Por. J. Hennesey SJ, Leo XIII: Intellectualizing the Combat with Modernity, „U.S. Catholic Historian" 7, 1988, 4 (Fall), s. 393-400, 〈http://www.jstor.org/stable/25153851〉 (dostęp: 16 VI 2015).

${ }^{40}$ Historia Kościoła, t. 5, s. 34 (sformułowanie Rogera Auberta).

${ }^{41}$ Historia Kościoła, t. 4, s. 260. 
absorbować i przetwarzać na swoją korzyść najróżniejsze wątki ideowe. Takim bijącym w oczy przykładem jest stosunek do idei ewolucji. Wydawać by się mogło, że nie powinno być żadnego problemu z jej uzgodnieniem z doktryną katolicką, dysponującą wszakże wypracowanym przez stulecia niezwykle finezyjnym aparatem interpretacyjnym pozwalającym na pogodzenie z Pismem św. najróżniejszych prądów filozoficznych i naukowych. Nic więc dziwnego, że przez trzydzieści lat od czasu publikacji głównego dzieła Darwina wielu katolickich teologów wyrażało się o teorii ewolucji z uznaniem, nie widząc w niej nic sprzecznego z nauką Kościoła. Dopiero w latach dziewięćdziesiątych XIX w. Święte Oficjum, inspirowane przez grupę opozycyjnych wobec Leona XIII konserwatywnych jezuitów skupionych wokół redakcji „La Civiltà Cattolica”, potępiło samą ideę ewolucji jako niezgodną z prawdą chrześcijańską. Potępienie to, dokonane pod sam koniec pontyfikatu Leona XIII, było jakby przygrywką do późniejszej o kilka lat kampanii antymodernistycznej, w której również „La Civiltà Cattolica" odegrała istotną rolę ${ }^{42}$.

Kościól, przestraszony nowoczesnością, zapomniał o swej własnej tradycji; zapomniał o podstawowej regule egzegetycznej wypracowanej jeszcze przez Orygenesa w III w. naszej ery, że Pismo św. ma sens cielesny (dosłowny) i sens alegoryczny, a tam, gdzie interpretacja dosłowna prowadzi do absurdu, należy stosować interpretację alegoryczną ${ }^{43}$. Literalne odczytanie Biblii nie jest przecież (jak zapewne wydawało się jego zwolennikom) przejawem katolickiego tradycjonalizmu, ale czymś odwrotnym - przejęciem idei fundamentalizmu biblijnego, do tej pory kojarzonego raczej z protestantyzmem. Szańce neoscholastyki dawać mogły poczucie złudnego bezpieczeństwa, ale w istocie odcinały Kościół nie tylko od nowoczesności, ale nawet od różnorodności i wielostronności autentycznej tradycji średniowiecznej, w której można było przecież znaleźć cały wachlarz inspirujących idei i poglądów.

Oryginalne stanowisko zajął tutaj, jak w tylu innych sprawach, John Henry Newman, zapewne najwybitniejszy myśliciel katolicki swego czasu. Jeśli przyjmiemy, że najważniejsze wyzwania intelektualne dla chrześcijaństwa w XIX w. stanowiły scjentyzm, historyzm i religijny irracjonalizm (była o tym już mowa), to wszystkie one znajdują się w refleksji Newmana na centralnym miejscu. W tej chwili interesuje nas problem historyzmu. W swojej pracy O rozwoju doktryny chrześcijańskiej (1845) Newman starał się

${ }^{42}$ B. Brundell, Catholic Church Politics and Evolution Theory, 1894-1902, ,,The British Journal for the History of Science" 34, 2001, 1 (March), s. 81-95, <http://www.jstor. org/stable/4028040> (dostęp: 23 III 2015).

${ }^{43}$ E. Gilson, Historia filozofii chrześcijańskiej w wiekach średnich, Warszawa 1987 (oryg. franc. 1955), s. 37. 
wykazać, że idea ciągłości doktryny chrześcijańskiej od czasów apostolskich po nasze dni nie wyklucza możliwości jej ewolucyjnych przemian. Tym samym ideę ciągłości doktryny chrześcijańskiej da się pogodzić z dominującym w dziewiętnastowiecznej humanistyce historyzmem. W kontekście sporu o ewolucję ważne jest, że Newman postawił się w rzędzie „pionierów nowoczesnego myślenia w terminach rozwoju" ${ }^{44}$ - wraz z Darwinem, Spencerem i kilkoma innymi myślicielami. Nic więc dziwnego, że Newman nie znalazł nic gorszącego czy sprzecznego z religią w Darwinowskiej teorii ewolucji - wszak wszechmoc Boża nie dozna uszczerbku, gdy się przyjmie, że stworzenie dokonuje się pośrednio i stopniowo, za pośrednictwem procesu ewolucyjnego, który sam jest przecież tworem Boskim ${ }^{45}$. Rozwiązanie Newmana nie znalazło jednak uznania w Kościele jego czasów.

Zapewne jeszcze większą porażką intelektualną była nieumiejętność wykorzystania potencjału myślowego ruchu z początku XX w. znanego pod nazwą katolickiego modernizmu. Jego bardzo mocne potępienie, bez prób rozróżnienia najrozmaitszych jego elementów, dotknęło w tym samym stopniu myślicieli wychodzących poza katolicyzm, jak i tych, „,dla których dogmat katolicki [--] był barierą nieprzekraczalną" ${ }^{46}$, wykopując między myślą dwudziestego wieku a Kościołem przepaść zdawałoby się nie do przekroczenia ${ }^{47}$.

Tak więc otwarcie na świat współczesny było ograniczone - ale nawet tak ograniczone (a może dlatego, że tak ograniczone?), otwarcie to miało swoją cenę. Kościół, budując swój nowoczesny obraz świata przeciw dominującemu modelowi nowoczesności racjonalno-liberalno-oświeceniowej, dokonywał wyboru politycznego i tym samym, chcąc nie chcąc, stawał się jedną z partii politycznych. Kiedy Kościół zaangażował się w ruch chrześcijańsko-społeczny, ten partyjny charakter jeszcze się nasilił. Można oczywiście mieć wątpliwości co do tej tezy. Czyż od zawsze Kościół nie definiował się przez wrogów? Czyż nastawienie takie nie wzrosło w dobie reformacji

${ }^{44}$ W. Ostrowski, Książka z Littlemore [wstęp], w: J.H. Newman, O rozwoju doktryny chrześcijańskiej, Warszawa 1957, s. 5-18, cyt. s. 12.

${ }^{45}$ Swoje poglądy na teorię Darwina wyraził Newman w liście do kanonika J. Walkera z 22 maja 1868 r., w: The Letters and Diaries of John Henry Newman, red. C.S. Dessain, T. Gornall, t. 24, Oxford 1973, s. 77-78, w Internecie dostępny na stronie: „Interdisciplinary Encyclopedia of Religion and Science”, 〈http://inters.org/Newman-Scarborough -Darwin-Evolution> (dostęp: 15 X 2015).

${ }^{46}$ Z. Zieliński, Papiestwo i papieże dwóch ostatnich wieków, Poznań 1986 (wyd. 2 popr. i uzup.), t.2, s. 36.

${ }^{47} \mathrm{Na}$ temat modernizmu katolickiego najważniejsze dla mnie były trzy książki: C. Arnold, Mała historia modernizmu, Kraków 2009 (oryg. niem. 2007); M.R. O’Connell, Critics on Trial. An Introduction to the Catholic Modernist Crisis, Washington, D.C. 1994; M. Zdziechowski, Pesymizm, romantyzm a podstawy chrześcijaństwa, t. 1-2, Kraków 1914. 
i kontrreformacji? Pewnie tak, ale od czasów oświecenia, a szczególnie Piusa IX, staje się ono mocniejsze, ze względu na to, że Kościół odcina się świadomie od różnych prądów nowoczesności. Kiedy zaś następuje za Leona XIII ostrożne i wybiórcze otwarcie na nowoczesność, owa „partyjność” Kościoła nie zanika, lecz jeszcze się wzmacnia. Partyjność Kościoła była w pewien sposób ceną za jego aktywizm - dopóki był bierny, nie była widoczna. Brian Porter-Szücs (którego książka o stosunku Kościoła do polskiej idei narodowej w końcu XIX i pierwszej połowie XX w. była dla mnie jedną z podstawowych inspiracji) zwraca uwagę na przemianę rozumienia pojęcia walki w Kościele. W przemianie tej można się dopatrzyć pewnego wpływu odrzucanej w zasadzie przez Kościół idei socjaldarwinizmu. Otóż Kościół zawsze wzywał do walki z zewnętrznymi wrogami, zawsze też podkreślał jednak, że najważniejszy front walki duchowej przebiega wewnątrz duszy każdego wiernego; wszyscy toczymy (by zacytować Mikołaja Sępa-Szarzyńskiego) „wojnę śmiertelną [--] z szatanem, światem i ciałem” (przy czym „świat” jest w powyższej formułce rozumiany jako pokusy, wiodące nas ku złemu). Teraz zaś wojna staje się wojną z wrogimi partiami politycznymi: wróg jest na zewnątrz. W sferze teologicznej oznacza to „odindywidualizowanie" katolicyzmu: postawy zbiorowe stają się ważniejszym tematem duszpasterstwa i przedmiotem uwagi duchowieństwa niż przeżycia indywidualne ${ }^{48}$. Porter-Szücs, analizując ten proces w odniesieniu do katolicyzmu polskiego, trafnie zauważa, że jest to jakby rewers powstania społecznej nauki Kościoła. Kościół zaczyna interesować się żywo problemami społecznymi, dostrzega ogrom nędzy robotniczej, szuka środków zaradczych - czyniąc to, buduje swój program społeczny, ale tym samym wchodzi w logikę funkcjonowania partii politycznej, ze wszystkimi tego konsekwencjami. Być może taka postawa była także po części efektem większego niż dawniej pluralizmu życia religijno-politycznego: w czasach obowiązywania zasady cuius regio, eius religio heretycy byli na obrzeżach społeczeństwa i wykład kaznodziejski nie na nich musiał się koncentrować, ale na indywidualnych grzechach osób wierzących. Teraz zaś wilki przemieszały się z owcami niemal nie do rozróżnienia.

Ale cena społecznego zaangażowania była jeszcze wyższa. Jednym z najbardziej fascynujących zjawisk jest zmiana stosunku Kościoła do nacjonalizmu. Ta zmiana jest - bez wątpliwości - formą modernizacji Kościoła. Rzućmy okiem na hasło Narodowość w Encyklopedii kościelnej, redagowanej przez księdza Michała Nowodworskiego. Czytamy tam - zupełnie w duchu Herdera - że ,indywidualne cechy, znamionujące narodowość,

${ }^{48}$ B. Porter-Szücs, Faith and Fatherland. Catholicism, Modernity and Poland, Oxford 2011, s. 232-272. 
tak samo jak odmienności jednostek ludzkich, są dziełem Opatrzności boskiej, wchodzącym do planu wszechświata; gdyż rozmaitość charakterów narodowych pozwala rodzajowi ludzkiemu wszechstronnie spełnić postawione mu zadanie; każdy lud przykłada się do jego spełnienia odpowiednio do swoich właściwości i swego uzdolnienia. Taki też jest pod tym względem zamiar mądrości Boskiej”. „Jedność rodzaju ludzkiego” istnieje ponad wszelkimi różnicami ludów i ras. „Wszyscy ludzie stworzeni na obraz i podobieństwo Boga, wszyscy posiadają takież same siły duchowe i fizyczne, wszystkim wytknięty został cel jeden, do którego dążyć mają pod kierownictwem Opatrzności boskiej. Wszyscy ludzie są członkami jednej olbrzymiej rodziny, której panem i prawodawcą jest Bóg. [--] Pycha narodowa jest tak samo potępienia godną, jak pycha w życiu prywatnym". Istnieją narody i istnieją państwa, „prawo istnienia” jednych i drugich „,jest prawem Boskim”. „Wolę Bożą gwałci więc ten, kto w imię narodowości podkopuje i obala związki państwowe, istniejące mocą prawa historycznego, jak również ten, kto w imieniu państwa i mniemanych interesów państwowych gnębi i wytępić usiłuje narodowość". Myśl jest jasna: narodowości mają prawo do istnienia, muszą być tolerowane przez władze państwowe, nie mają natomiast prawa do budowy państw narodowych. Niestety - dziś na świecie panuje „liberalizm, ze swymi materialistowskimi dążeniami. On to jest ojcem nowoczesnej «zasady narodowości», która pozostając w zupełnej sprzeczności z chrześcijańskim pojmowaniem narodowości, tyle już klęsk sprowadziła na Europę. Stronnicy tej doktryny” uważają, że „narodowe i państwowe organizmy powinny się wzajemnie zupełnie pokrywać". Jak samolubstwo ma być motorem działań jednostek, tak egoizm - ludów, efektem zaś jest nienawiść. „Zamykając każdą narodowość w sobie samej, musi ona [zasada narodowości w rozumieniu liberalnym - M.J.] pracować nad rozerwaniem jedności Kościoła"49.

Minęło trzydzieści lat. W kwietniu 1913 r. polscy biskupi galicyjscy ogłosili w prasie list otwarty w sprawie przygotowywanej przez krakowskich konserwatystów (przede wszystkim ówczesnego namiestnika Galicji, Michała Bobrzyńskiego) reformy wyborczej ${ }^{50}$. Pod listem podpisali się arcybiskupi lwowscy obrządku łacińskiego (Józef Bilczewski) i ormiańskiego (Józef Teodorowicz) oraz biskupi obrządku łacińskiego krakowski (Adam Sapieha), przemyski (Józef Pelczar) i tarnowski (Leon Wałęga). Od wielu lat trwały w Galicji prace nad tą reformą ${ }^{51}$ i przed samą finalizacją biskupi

${ }^{49}$ J.N. [J. Nowodworski], Narodowość, w: Encyklopedia kościelna podług teologicznej encyklopedii Wetzera i Weltego z licznymi jej dopetnieniami, red. ks. M. Nowodworski, t. 15, Warszawa 1883, s. 548-558.

${ }^{50}$ Pismo XX Biskupów polskich, „Czas” 66, 17 IV 1913, nr 177, wyd. popołudniowe, s. 1.

51 Jedyną całościową monografią pozostaje po dziś dzień książka Józefa Buszki, 
zgłosili swój sprzeciw. Nie miejsce tutaj, aby analizować szczegółowo całą sprawę; chodzi o to, że sprzeciwiając się reformie, biskupi uplasowali się jednoznacznie po stronie Narodowej Demokracji, a przeciw krakowskim konserwatystom. Była to rewolucja w polskiej polityce - rewolucja, której znaczenia historiografia polska chyba wciąż jeszcze nie docenia w pełni. Narodowa Demokracja zajęła miejsce tradycyjnego konserwatyzmu i zaczęła dominować po prawej stronie polskiej sceny politycznej.

Widać wyraźnie: coś bardzo ważnego zaszło w myśli katolickiej w ćwierćwieczu poprzedzającym I wojnę światową. Przemiana dojrzewała powoli i stopniowo, z zachowaniem dużej części frazeologii, do tego stopnia, że dla niektórych - zarówno nadawców, jak i odbiorców - może być w ogóle niezauważona. Język sprzeciwu wobec radykalizmu jest tak samo silny w cytowanym haśle z Encyklopedii kościelnej jak i u galicyjskich biskupów; zarówno hasło w Encyklopedii, jak i list biskupów wyrażają zaniepokojenie tym, że nacjonalizm wprowadza rozbicie między chrześcijan; różnica polega jedynie na tym, że w pierwszym wypadu sensem wypowiedzi jest zdystansowanie się Kościoła od ruchu narodowego, w drugim zaś opowiedzenie się po stronie tegoż ruchu.

Jest jednak także i istotna różnica we frazeologii. Kościół galicyjski, co mocno podkreśla Porter-Szűcs, przejął się mocno ideami Rerum novarum $^{52}$. Sygnatariusze listu, a szczególnie biskupi Pelczar i Bilczewski, należeli do najgorliwszych propagatorów nowego zaangażowania społecznego. Idee sprawiedliwości społecznej i demokratyzacji, tak wyraźnie (zwłaszcza druga z nich) obecne w dokumencie biskupów, są wyraźnym znakiem nowego pojmowania roli Kościoła w świecie. Nacjonalizm nie jest otwarcie proklamowany w omawianym liście, niemniej stanowi jego myślową podstawę. Istotą głębokiej i subtelnej sztuki kompromisów narodowościowych w Austro-Węgrzech, tych dokonanych i tych (liczniejszych) tylko projektowanych, było takie wyważenie systemu politycznego, aby żadna $\mathrm{z}$ narodowości $\mathrm{w}$ wieloetnicznym regionie nie była zmajoryzowana przez inne. Służą temu kurie narodowościowe w instytucjach przedstawicielskich, a także podział okręgów wyborczych między narodowości, tak aby każdej z nich zapewnić reprezentację. Otóż przeciwko temu przede wszystkim wypowiadają się biskupi. Argumentacja jest czysto nacjonalistyczna: wykrojenie okręgów wyborczych tak, aby zapewnić reprezentację różnym narodowościom (w tym także, jak wyrażają się biskupi, „ludności niechrześcijańskiej”, co w gali-

Sejmowa reforma wyborcza w Galicji, 1905-1914, Warszawa 1956. Cenna pod względem faktograficznym, interpretacyjnie pozostaje niestety pod bardzo silnym wpływem epoki, w której powstała. Ogólne zasady reformy przedstawione tamże, s. 226-229.

${ }^{52}$ B. Porter-Szücs, op. cit., s. 125, 130-132. 
cyjskim kontekście musi oznaczać Żydów) oznacza, że ci Polacy, którzy pozostaną poza wykrojonymi dla Polaków okręgami, są dla „ludności chrześcijańskiej” straceni (tzn. ich głosy „zmarnują się” podczas wyborów). Deklarując życzliwość wobec ludu „ruskiego” i wobec „bratniego obrządku" greckokatolickiego, biskupi sprzeciwiają się osobnym okręgom wyborczym dla Polaków i Ukraińców. W ten sposób niszczą sam sens reformy - próbę kompromisu polsko-ukraińskiego, bo brak takiego rozróżnienia działa na korzyść narodowości silniejszej, tj. Polaków. Zajmują więc, nie mówiąc tego wprost, pozycję bardzo bliską stanowisku Narodowej Demokracji.

Silnie opowiadając się za demokratyzacją, biskupi wyjaśniają motywy tego nastawienia: chłop polski jest pełen szacunku do Kościoła, jest ostoją wiary i narodowości, on był główną siłą sprzeciwiającą się kulturkampfowi w zaborze pruskim. Aby jednak polskie społeczeństwo wyrazić mogło swą prawdziwą duszę (właśnie taką, jak przedstawiono powyżej), musi być wolne od radykalizmu, którego przejawem jest zamierzona reforma wyborcza. Na czym ten radykalizm reformy wyborczej polega, z listu się nie dowiemy. Wiadomo skądinąd, że rolę odegrała osoba antyklerykalnego lewicowego ludowego działacza Jana Stapińskiego, wówczas popierającego stańczyków przeciw endecji - jednak wydaje się, że chodzi tu o kwestię ogólniejszą. Kościołowi łatwiej (choć bez entuzjazmu) przychodzi pogodzić się z demokratyzacją (czyli ze wzrastającym wpływem mas na życie polityczne) niż z liberalizmem rozumianym jako idea swobody jednostki, zarówno w dziedzinie działania, jak i sumienia. Demokracja, jak długo większość społeczeństwa była tak czy inaczej katolicka, dawała możność zachowania kościelnej dominacji; system natomiast, który ma wbudowane mechanizmy ochrony mniejszości (a na tym przecież polegać musiał kompromis między narodowościami), budzi niechęć i nieufność biskupów: atomizuje, wprowadza rozdźwięk, do pewnego stopnia umożliwia też jednostkom zachowania nonkonformistyczne, jest więc przejawem owego niebezpiecznego radykalizmu.

Choć wspomniany list nie zawiera żadnych deklaracji antysemickich, pojawiają się one w polemicznym tekście jednego z sygnatariuszy, abp. ormiańskiego Teodorowicza, który w swych poglądach politycznych zapewne z całej piątki stał najbliżej endecji (i który, jak pisze Waldemar Łazuga, był spiritus movens listu biskupów) ${ }^{53}$. W 1916 r. Bobrzyński opublikował anonimowo broszurę Dialog o zasadach $i$ kompromisach, broniącą polityki, która stała u podstaw projektu reformy wyborczej z $1913 \mathrm{r}$.

${ }^{53}$ W. Łazuga, Michał Bobrzyński. Myśl historyczna a działalność polityczna, Warszawa 1982, s. 166. 
Teodorowicz zareagował (również wydaną anonimowo) broszurą polemiczną ${ }^{54}$, w której wyjaśniał m.in. motywy sprzeciwu wobec projektu reformy. Bobrzyński bronił m.in. polityki integracji Żydów z polskością, na co Teodorowicz zarzucił Bobrzyńskiemu, że w cyniczny sposób posługuje się Żydami przeciw Polakom w swej polityce i porównał taką postawę z wykorzystywaniem Żydów przez szlachtę dla ucisku chłopów drogą propinacji.

To wszystko jednak nie wyjaśnia do końca mechanizmu owego przerzucenia poparcia od stańczyków na endecję. Reforma wyborcza, przeciw której zwracali się galicyjscy biskupi, nie była przecież dziełem żadnych radykałów-rewolucjonistów, ale konserwatystów krakowskich, którzy rządzili prowincją od prawie pół wieku i uważali się niemalże z urzędu za obrońców wiary i Kościoła. Można sobie wyobrazić szok i zdezorientowanie w środowisku stańczyków. Hrabiemu Stanisławowi Tarnowskiemu musiało pewnie być bardzo przykro, gdy plotka krążąca po Galicji głosiła, że abp Teodorowicz w prywatnej rozmowie uznał go za „najgroźniejszego wroga Kościoła”55; Stanisław Smolka pisał, że „od 913 lat, odkąd istnieje polski episkopat”, nie było „równie szkodliwego” kroku biskupów ${ }^{56} \cdot \mathrm{Z}$ drugiej strony Narodową Demokrację otaczała jeszcze wówczas aura ugrupowania radykalnego; jej bojowy antysemityzm (którego rozkwit przypadł właśnie kilka miesięcy wcześniej, na czas kampanii wyborczej do Dumy w Królestwie Polskim jesienią 1912 r.) ciągle jeszcze szokował wielu zarówno na prawicy, jak i na lewicy, obecne w jej doktrynie elementy rasizmu i socjaldarwinizmu powinny właściwie zrażać duchownych, a większość jej przywódców, z Romanem Dmowskim na czele, wychowana w atmosferze pozytywizmu, daleka była od jakichkolwiek sympatii religijnych. Postawa biskupów musiała więc dziwić.

Historia ewolucji postaw biskupów galicyjskich, z punktu widzenia Kościoła powszechnego oczywiście marginalna, jest doskonałą egzemplifikacją sposobu, w jaki Kościół przełomu XIX i XX w. reagował na modernizacyjne przemiany. Działał - jak sądzę - następujący mechanizm: społeczna aktywność Kościoła, wywołana przez nowe potrzeby związane $\mathrm{z}$ wielkimi przemianami społeczno-gospodarczymi, trwa przez cały XIX w., aż zostaje usankcjonowana i włączona do samego centrum nauki Kościoła przez encyklikę Rerum novarum. W praktyce duszpasterskiej owo zaangażowanie społeczne zderzało się z zaangażowaniem społecznym ruchu socjaldemokratycznego, a także z modernizacją o charakte-

${ }^{54}$ [J. Teodorowicz], Stańczyk bez teki. Odpowiedź na „Dialog o zasadach i kompromisach", Warszawa 1917.

55 O tej wypowiedzi Teodorowicza informował Bobrzyńskiego Władysław Leopold Jaworski w liście z dn. 17 grudnia 1913 r., zacytowanym u J. Buszki, op. cit., s. 256.

${ }^{56}$ List S. Smolki do M. Bobrzyńskiego, 24 IV 1913, cyt za: W. Łazuga, op. cit., s. 166. 
rze liberalno-oświeceniowym, a temu zderzeniu sprzyja coraz powszechniejsze przyjmowanie formuły partii politycznej przez nurty chrześcijańsko-społeczne. Partia polityczna żyje przecież z konfliktu z innymi partiami. Trzeba było jasno odróżnić się od wszelkich innych (na ogół bardziej lewicowych) form aktywności społecznej. W tej sytuacji katolicki ruch społeczny na przełomie XIX i XX w. samą siłą inercji dryfuje w stronę nacjonalizmu i nowoczesnego antysemityzmu. Tradycyjne uprzedzenie antyżydowskie istniało oczywiście w Kościele „od zawsze”, a idee antysemickie widoczne były w różnych środowiskach katolickich (jak we wszystkich chyba środowiskach w ówczesnej Europie), teraz jednak mamy do czynienia z czymś nowym - z antysemickim ruchem społecznym, który wyrasta w katolickich środowiskach lokalnych, często przy oporze tradycyjnej hierarchii. Ruch chrześcijańsko-społeczny w Austrii czy aktywność księdza Stanisława Stojałowskiego w Galicji stanowią tu dobre przykłady. Antysemicki czy nacjonalistyczny element łączy się często z autentycznym zaangażowaniem społecznym (jak w wypadku Stojałowskiego), zwykle zresztą nie da się oddzielić jednego aspektu od drugiego. Uspołecznienie katolicyzmu (a zapewne i protestantyzmu też) w większości wypadków oznacza na przełomie XIX i XX w. wzrost jego podatności na mniej lub bardziej radykalne hasła nacjonalistyczne.

Póki Kościół był w swej większości obojętny na kwestie społeczne, póty mógł pozostawać z wyniosłym dystansem wobec nowoczesnego nacjonalizmu i nowoczesnego radykalnego antysemityzmu, traktowanych z rezerwą jako ruchy plebejskie. W momencie jednak, w którym zdecydował się, że w kwestiach społecznych nie może milczeć, że głos mas powinien być bardziej brany pod uwagę, zaangażowania nacjonalistycznego trudno było uniknąć. Nie chcę wartościować. Rerum novarum była wydarzeniem epokowym, a w ówczesnej sytuacji mentalnej zapewne uniknięcie silnych wpływów nacjonalistycznych i antysemickich było bardzo mało prawdopodobne. Niemniej efekt był taki, że Kościół zdołał powstrzymać dechrystianizację za cenę mocnego przesunięcia w stronę nacjonalistycznej prawicy. Jak wynika z badań Ilony Zaleskiej, niemal jedynym w Polsce początków XX w. środowiskiem katolickim zdecydowanie przeciwstawiającym się endeckiemu nacjonalizmowi było środowisko właśnie najbardziej konserwatywne, integralnie antymodernistyczne, skupione wokół wychodzącego w Częstochowie czasopisma „Myśl Katolicka”. To samo środowisko krytykowało abp. Teodorowicza jako zwolennika katolicyzmu liberalnego ${ }^{57} \mathrm{i}$ atakowało „prąd ten

${ }^{57}$ I. Zaleska, Kościół a Narodowa Demokracja w Królestwie Polskim do wybuchu I wojny światowej, Warszawa 2014, s. 333. 
zwyrodniałej miłości ojczyzny [--] pod nazwą skrajnego nacjonalizmu", który „bierze swe źródło w spoganieniu naszych społeczeństw” ${ }^{58}$. Widać, że w swym stosunku do nacjonalizmu „Myśl Katolicka” zatrzymała się na cytowanym wyżej haśle Encyklopedii kościelnej, zrównującym nacjonalizm, liberalizm i dechrystianizację, ale widać z tego i coś więcej: katolik nie był w stanie krytykować (a w każdym razie było mu niezwykle trudno to czynić) endeckiego nacjonalizmu inaczej niż z pozycji ultratradycyjnych. Nowoczesny katolik A.D. 1910 coraz częściej był nacjonalistą.

W wypadku polskim dochodzi jeszcze fascynująca kwestia teologii narodu. Sama idea nie jest czymś nowym, może odwoływać się do wzorów średniowiecznych, barokowych, a także późniejszych; w Polsce do Jana Pawła Woronicza, a także do heterodoksyjnych i odrzucanych przez Kościół, ale bardzo wpływowych w kulturze polskiej idei romantycznego mesjanizmu. Teraz jednak zaczyna się tworzyć spójna myśl teologiczna przyznająca „narodowi ochrzczonemu” jako całości specjalny status ontologiczny i specjalne miejsce w Bożych planach. W pełni zostanie ona rozwinięta przez kardynała Stefana Wyszyńskiego w czasach komunistycznych.

Jest niezwykle ważne dla tematyki niniejszego szkicu, że ów zwrot na prawo ku nacjonalizmowi i antysemityzmowi nie był żadną formą odejścia Kościoła od nowoczesności, kompromisu z tradycją i przednowoczesnymi formami życia społecznego itp. Przeciwnie - był on właśnie formą modernizacji katolicyzmu, przystosowania się Kościoła do wymogów nowoczesnej polityki w epoce masowych partii politycznych. W porównaniu z katolicyzmem poprzednich pokoleń poparcie dla nacjonalizmu było zmianą rewolucyjną ${ }^{59}$. Stanowiło ono aspekt zjawiska, o którym była mowa wcześniej: modernizacji drogą tworzenia modelu nowoczesności alternatywnego wobec nowoczesności liberalno-oświeceniowej.

Dlaczego właściwie modernizacja Kościoła poszła w tym kierunku? Dokładniej, odważę się postawić pytanie: dlaczego właściwie Kościół nie poparł głównego nurtu dziewiętnastowiecznej nowoczesności, tj. nurtu oświeceniowo-liberalnego? Przecież rewolucyjna przemiana na drodze przystosowania do nowoczesności i tak została już podjęta; przejęcie problematyki społecznej i zbliżenie do nowoczesnej prawicy było nie mniej radykalnym zerwaniem z tradycją niż byłaby nim ewentualna akceptacja ideałów oświeceniowych.

Tym bardziej że przecież oświecenie - badania z ostatnich kilku dziesiątków lat ukazały to ponad wszelką wątpliwość - było o wiele

${ }^{58}$ Odsłoniły się karty, „,Myśl Katolicka” 23 VI 1908, nr 16, cyt. wg I.Zaleska, op. cit., s. 340.

${ }^{59}$ Por. B. Porter-Szűcs, op. cit., s. 206-207. 
mniej antyreligijne, niż ukazuje to stereotypowy obraz. Pisałem już o chrześcijańskim oświeceniu niemieckim, ale przecież dotyczy to także i innych krajów. Nawet rewolucja francuska początkowo nie była skierowana przeciw Kościołowi. Najprostsza odpowiedź na powyższe pytanie mogłaby brzmieć: „bo oświecenie było wcześniej”60. Skoro Kościół już w XVIII w. zwrócił się przeciw tradycji oświeceniowej, to niejako automatycznie w ciągu następnego stulecia wieku zbliżył się do nurtów antyoświeceniowych - prawicowych i nacjonalistycznych. Nie zwrócił się przeciw nowemu nacjonalizmowi, bo stanowisko „głównego złego” było już zajęte. Trzeba do tego dodać jeszcze jeden czynnik, tj. oddziaływanie rewolucji francuskiej: terror, a potem napoleońskie upokorzenie papiestwa, odepchnęły Kościół od oświecenia. Wbrew podręcznikowemu obrazowi sądzę bowiem, że rewolucja osłabiła, a nie wzmocniła, europejskie oddziaływanie idei oświeceniowych. Dotyczy to zarówno zmiany postawy monarchów i elit (odejście od oświeconego absolutyzmu i od ideałów reformistycznych na rzecz sztywnego konserwatyzmu), jak i właśnie Kościoła. Rewolucja sprawiła, że ex post oświecenie było postrzegane przez pryzmat jednostronnie widzianego oświecenia francuskiego - jako nurt myślowy radykalnie antychrześcijański, prowadzący nieuchronnie do terroru i radykalnego przewrotu społecznego. $Z$ tak postrzeganym oświeceniem Kościół nie chciał mieć nic wspólnego.

A przecież istniał przez cały XIX w. nurt - czasem słabszy, czasem mocniejszy - liberalizmu katolickiego. Liberałowie katolicy proponowali próbę takiej modernizacji Kościoła, która nie byłaby „modernizacją alternatywną”, ale „wciągnięciem” Kościoła w główny nurt postoświeceniowych przemian przez przejęcie przez Kościół podstawowego paradygmatu oświeceniowego w katolickiej wersji. Jeden z najwybitniejszych przedstawicieli tego nurtu, hrabia Charles de Montalembert, starał się przekonać swych współwyznawców do zalet wolności politycznej i systemu parlamentarno-konstytucyjnego. Podkreślał, że pierwsza połowa XIX w. była epoką rozkwitu katolicyzmu w warunkach wolności religijnej.Jak wszyscy liberałowie katoliccy, jako koronny przykład podawał Belgię, w której liberalny system polityczny łączył się z bezprecedensowym rozwojem Kościoła. Zarazem poparcie dla wolności nie było motywowane względami taktycznymi, lecz zasadniczym uznaniem, że „wolność jest jedną z sił żywotnich ludzkości”, „religia zaś jest jej rękojmią”61. Jeśli liberałowie popełnili błąd, atakując religię i negując istnienie porządku nadprzyrodzonego, to katolicy

${ }^{60}$ Tę myśl zasugerował mi w rozmowie M.Górny.

${ }^{61}$ „la liberté est une des forces vitales de l'humanité”, „la religion est sa sauvegarde", Ch. de Montalembert, Des intérêts catholiques au XIXe siècle, Bruxelles 1852, s. 27. 
odpowiedzieli analogicznym błędem, odrzucając wolność. Ostrzegał przed zaangażowaniem Kościoła po stronie despotycznych monarchów: „Spośród wszystkich despotyzmów najbardziej niemożliwym do zniesienia dla narodów naszej epoki jest ten, który jest praktykowany (lub wydaje się, że jest praktykowany) za zgodą religii. Znosi on najlepsze odczucia naszej duszy, ponieważ wyczuwa się w nim nadużycie świętej sprawy dla świeckich interesów"62.

Konserwatyści katoliccy natomiast sądzili, podobnie jak niektórzy radykałowie antyklerykalni, że liberałowie katoliccy, nawet jeśli subiektywnie działają w dobrej wierze, podkopują Kościół, bo obiektywny proces racjonalizacji świata podkopuje religię. Jest w tym ze strony katolickich konserwatystów inherentnie pesymistyczne założenie - nie tylko pesymistyczne metafizycznie, o niemożności osiągnięcia doskonałości z powodu grzechu pierworodnego, ale pesymistyczne historiozoficznie, że czas i postęp gra na korzyść antyklerykałów - sekularystów. Wydawać by się mogło, że katoliccy tradycjonaliści przejmują tutaj wiarę ludzi oświecenia w postęp rozumu i opatrują ją znakiem przeciwnym. Najpopularniejszy antyliberalny polemista katolicki, Louis Veuillot, jakby polemizując z powyższym cytatem Montalemberta, odrzucał wszelkie roszczenia wolnościowe i przedstawiał bardzo zdecydowanie koncepcje państwa monarchicznego, w którym normy moralne, definiowane przez Kościół, są narzucane przez prawo. Nie ma i nie może być wolności w sensie tolerancji błędnych opinii i zachowań: „Nie, nie ma wcale wolności ludzkiej w tym niebezpiecznym sensie; Bóg nie dał skłonnym do upadku istotom tego niebezpiecznego daru. Jedynie Bóg jest wolny. Dał nam wolną wolę, lecz nie wolność"63.

Skomplikowaną grę sił między katolikami konserwatywnymi i liberalnymi widać doskonale na przykładzie sporów wokół Syllabusa. Najbardziej znany, wręcz podręcznikowy przejaw siły tradycyjnego katolicyzmu czasów Piusa IX to Syllabus błędów, opublikowany przez papieża w 1865 r. jako dodatek do encykliki Quanta cura. Zawierał on w osiemdziesięciu punktach listę poglądów potępionych przez papieża (a więc każde jego stwierdzenie ma przed sobą domyślną frazę „nieprawda, że”). Zarówno dla ultramontan, jak i dla antyklerykałów stał się on ulubio-

62 „De tous les despotismes, le plus intolérable aux nations de nos jours est celui qui s'exerce ou semble s'exercer avec le concours de la religion. Il soulève les meilleurs sentiments de notre âme, parce qu'on y sent l'exploitation d'une chose sainte au profit d'un intérèt profane", ibidem, s. 107-108.

63 „Non, il n'y a point de liberté humaine dans ce sens périlleux; Dieu n'a point fait ce dangereux présent à des êtres faillibles. Dieu seul est libre. Il nous a donné le libre arbitre, point la liberté", L. Veuillot, L'illusion libérale, Paris 1866 (wyd. 5), s. 50. 
nym dokumentem: ci pierwsi widzieli w nim tryumf prawdziwej wiary, ci drudzy - dowód anachronizmu papiestwa i jego upadku intelektualnego. Tymczasem rzecz była o wiele ciekawsza i o wiele bardziej skomplikowana.

Oto w kilka miesięcy później ukazała się niewielka książka biskupa Orleanu, Félixa Dupanloup, głośnego polemisty uważanego za sympatyka katolików liberalnych, poświęcona obronie Syllabusa przed atakami antyklerykałów. W pierwszej części pracy Dupanloup ostro skrytykował konwencję między Francją a Piemontem, w której Napoleon III po raz pierwszy dopuszczał możliwość przekazania Rzymu zjednoczonym Włochom. Dla nas ważna jest druga część, stanowiąca szczegółową analizę Syllabusa. Zbrojny w uświęcone przez wielowiekową tradycję metody egzegezy biblijnej, Dupanloup dokładnie analizuje poszczególne punkty Syllabusa, aby wykazać, że ataki antyklerykałów nie mają żadnych podstaw. Jego naczelny argument wywodzi się z logiki formalnej: jeżeli punkty Syllabusa mają postać zaprzeczeń (nie jest prawdą, że... etc.), to zdaniem prawdziwym nie jest zdanie przeciwne zdaniu zaprzeczonemu, tylko zaprzeczenie zaprzeczenia (zaprzeczeniem zdania mówiącego, że „nie q”, nie jest „q”, ale „istnieje przynajmniej jeden taki przypadek, że q"): jeśli papież w Syllabusie potępia pogląd, że ludzie mają prawo nie słuchać swej legalnej władzy, to nie wynika z tego, że ludzie zawsze muszą słuchać władzy, tylko że istnieją takie przypadki, w których ludzie muszą jej słuchać6 ${ }^{64}$. Podobnie z potępieniem przez papieża poglądu, że państwa nie powinny interweniować $\mathrm{w}$ wewnętrzne sprawy innych państw. Papież nie może przecież mieć na myśli, że interwencja zawsze jest dopuszczalna, bo byłoby to absurdem. Chodzi mu o to, że istnieją sytuacje, kiedy można dopuścić taką interwencję - a takie zdanie nie jest przecież niczym spornym. W tym ostatnim wypadku Dupanloup - zgodnie pismem kard. Giacoma Antonellego wspomnianym niżej - odwołuje się także do kontekstu całości wymienionych w Syllabusie wypowiedzi papieskich, co pozwalało wykazać, że potępienia, mające w Syllabusie formę zdań ogólnych, w istocie odnoszą się jedynie do pewnych konkretnych sytuacji. Najtrudniejsze było znane sformułowanie, że papież „powinien pogodzić się ze współczesną cywilizacją”. Przecież - pisze Dupanloup - nie można „pogodzić się” lub „nie pogodzić” z czymś, co jest dobre, bo rzeczy dobre po prostu się akceptuje i tyle. Papieżowi chodziło więc o to, że nie może pogodzić się z negatywnymi stronami współczesnej cywilizacji, natomiast jej strony pozytywne jak najbardziej

${ }^{64}$ F. Dupanloup, La Convention du 15 Septembre et l'encyclique du 8 Decembre, Paris 1865, s. 101. 
pochwala ${ }^{65}$. Wreszcie, kiedy papież krytykuje „współczesny liberalizm”, Dupanloup wyjaśnia: przymiotnik „współczesny” ma znaczenie ograniczające. Skoro papież go użył, to najwyraźniej chciał przez to podkreślić, że potępia tylko pewną konkretną odmianę liberalizmu, mianowicie liberalizm współczesny, nie zaś liberalizm jako taki. Dalej następuje wywód historyczny mający wykazać, że Kościół zawsze stał po stronie wolności - a więc zarzucanie mu niechęci do liberalizmu jest dowodem ignorancji i skrajnej antyklerykalnej stronniczości ${ }^{66}$.

Książka Dupanloupa stanowi dla historyka nie lada wyzwanie interpretacyjne. Z jednej strony, jego argumentacja odwołuje się do zasad hermeneutycznych obecnych w egzegezie katolickiej od wieków (choć, jak była mowa wcześniej, zmarginalizowanych w XIX w.). W teologii „trzeba wiele rozróżniać, aby nie pobłądzić wiele. Prawda ma nieskończone niuanse, i trzeba umieć odróżniać te niuanse i nie mieszać ich ze sobą"67. Dupanloup ma bez wątpienia rację, podkreślając, że punkty Syllabusa dotyczą często spraw konkretnych, a nie ogólnych, że potępienia pewnych tez jako fałszywych nie oznaczają jeszcze, że tezy im przeciwne są prawdziwe. Pius IX skierował do Dupanloupa list z podziękowaniem za obronę przed atakami wrogów Kościoła - biskup Orleanu zaś drukował go odtąd na początku swej książki jako jej swoistą immunizację przeciwko ewentualnej krytyce. Dodać jeszcze można, że Syllabus nie był adresowany do ogółu wiernych, tylko do biskupów, a także nie stanowił części encykliki Quanta cura, lecz tylko był rozesłany biskupom wraz z nią. Przygotowany został, jak mówi o tym dołączone doń pismo przewodnie sekretarza stanu, kard. Antonellego, jako rodzaj wykazu wypowiedzi papieskich na temat współczesności: każdy punkt był skróconym cytatem z jakiejś wypowiedzi papieża wraz z odnośnikiem do całości tej wypowiedzi. Każdy z punktów, jak przypominał adresatom Syllabusa Antonelli, może być rozumiany tylko w kontekście całości danej wypowiedzi, nigdy zaś sam w sobie. Z drugiej strony jednak można zapytać „co z tego?”. Syllabus dotarł do czytelników - wiernych i innych - w takiej formie, w jakiej do dziś jest znany, w formie listy potępionych tez, bez żadnych wyjaśnień czy dodatków. Stolica Święta nigdy nie zdystansowała się wobec takiego odbioru Syllabusa, jaki był obiektem krytyki biskupa Dupanloupa.

Amerykański historyk Marvin R. O'Connell (z którego artykułu dowiedziałem się o całej tej historii) proponuje frapującą interpretację. Jego

${ }^{65}$ Ibidem, s. 104.

${ }^{66}$ Ibidem, s. 115-118.

67 „il faut beaucoup distinguer, sous peine de beaucoup confondre. La vérité a des nuances infinies, et il faut savoir discerner ces nuances, ou ne pas s'en mêler", ibidem, s. 106. 
zdaniem książka Dupanloupa jedynie pozornie zwraca się przeciw antyklerykałom; w istocie jej głównym adresatem są katoliccy tradycjonaliści, i właśnie w kontekście sporu dwóch nurtów wewnątrz Kościoła należy ją odczytywać. Mamy tu do czynienia z pewnym implicite zawartym (choć nigdy explicite nie ogłoszonym) kompromisem, na którym opierało się w zasadzie całe funkcjonowanie liberalnego i konserwatywnego skrzydła w Kościele przez sto lat między pontyfikatem Piusa IX a Soborem Watykańskim II (może należałoby dodać „a także i później”?). Kompromis ów zasadzał się na tym, że katolickim tradycjonalistom udaje się skłonić Rzym do wydania bardzo konserwatywnych dokumentów, natomiast katoliccy liberałowie przeprowadzają później taką ich interpretację, która istotnie łagodzi ich ostrość. Rzym zaś nie opowiada się jasno po żadnej ze stron, aby nie podsycać sporu. W ten sposób utrzymuje się chwiejna równowaga między oboma skrzydłami. Tak samo, zdaniem O'Connella, miała się sprawa z dogmatem o nieomylności papieskiej. W $1865 \mathrm{r}$. Newman przewidywał, że nieomylność papieska, jeśli zostanie oficjalnie ogłoszona, będzie obudowana tyloma ograniczeniami, że wszystko pozostanie po staremu („,that it will leave things as they are”) ${ }^{68}$. I tak też się stało.

Myślę, że interpretacja O'Connella jest trafna. W początku XX w. nawet bardzo zasadnicze i wydawałoby się niepozostawiające miejsca na kompromis potępienie modernizmu katolickiego encykliką Pascendi dominici gregis (1907) mogło zostać do pewnego stopnia rozbrojone w podobny sposób. List pasterski episkopatu niemieckiego ze stycznia $1908 \mathrm{r}$. wyrażał radość, że „systemu [--] potępionego w encyklice [- - nie broni chyba żaden duchowny ani świecki w Niemczech". Niemiecki historyk, z którego książki zaczerpnąłem ten cytat, słusznie komentuje, że taka interpretacja stawia na głowie główną ideę encykliki, która wyraźnie mówi, że jej celem jest zdemaskowanie zasad, do których sami moderniści się nie przyznają ze względów taktycznych ${ }^{69}$.

Taki kompromis oczywiście nie zadowalał ani tradycjonalistów (jak Veuillot), ani bardzo pryncypialnych (nieżyczliwy historyk mógłby powiedzieć, że nieco doktrynerskich) ${ }^{70}$ katolickich liberałów takich jak lord Acton, który ostro krytykował Dupanloupa i Newmana za ich postawę, uznawaną przezeń za oportunistyczną. Acton sprzeciwiał się fałszywej jego zdaniem trosce o „dobro Kościoła”, która każe ukrywać prawdę albo

${ }^{68}$ O'Connell, Ultramontanism and Dupanloup, s. 217.

${ }^{69}$ C. Arnold, op. cit., s. 117-118.

70 Por. przede wszystkim G. Himmelfarb, Lord Acton, Chicago 1952, a także (polemiczne względem poprzedniego): T. Murphy, Lord Acton and the Question of Moral Judgments in History: The Development of His Position, „The Catholic Historical Review” 70, 1984, 2 (April), s. 225-250, 〈http://www.jstor.org/stable/25021806〉(dostęp: 12 VI 2015). 
zwalczać idee, które mogą zaszkodzić Kościołowi. Zwracał uwagę, że o ile na poziomie teologicznym istnieje jasny rozdział między prawdami wiary a zaleceniami, które nie wiążą katolika w sumieniu, o tyle w praktyce duszpasterskiej Kościół stara się zacierać to rozróżnienie i przedstawiać najróżniejsze nakazy jako prawdy wiary. Niemniej jednak kompromis, o którym tu mówimy, pozwolił na zachowanie w Kościele nurtu liberalnego. Niezależnie od tego, czy nurtowi temu przyznamy rację, czy nie, samo jego istnienie podtrzymywało debaty i podnosiło poziom intelektualny myśli katolickiej - a tym samym było ważnym czynnikiem sprzeciwiającym się dechrystianizacji.

Najtrudniejszą częścią będzie próba podsumowania. W każdej epoce historycznej dostrzegamy tendencje o przeciwstawnych wektorach. Często są niemal tak samo silne, a o zwycięstwie może zadecydować marginalna przewaga. Często zaś o zwycięstwie decydujemy my - historycy, kiedy patrząc ex post, przyznajemy jednej z tendencji przewagę nad inną, wprowadzając w chaos wydarzeń złudny ład, który w rzeczywistości istnieje jedynie w naszych umysłach. Świadom tego zagrożenia, zaryzykuję opinię, że per saldo - nie możemy mówić o dechrystianizacji Europy w XIX w. Nowoczesność różnicuje - rozmaite dane liczbowe mówią nam z jednej strony o masach mieszkańców miast zachodnioeuropejskich odchodzących od nabożeństw i sakramentów, a z drugiej strony - często w tym samym czasie i tych samych krajach - o wzroście powołań kapłańskich i zakonnych. Tworzą się - jak była o tym mowa - coraz szersze środowiska, w których niewiara jest normą, a z drugiej strony państwowa szkoła powszechna, tak niechętnie widziana przez Kościól, rozpowszechnia w masach - dzięki obowiązkowej nauce religii - wiedzę religijną w stopniu być może wyższym niż w jakiejkolwiek wcześniejszej epoce. Wpływy chrześcijaństwa w wielu dziedzinach słabną, w innych jednak się umacniają - odejście mas od religii nie dokonuje się. W tym sensie wiek XIX nie jest zapowiedzią drugiej połowy $\mathrm{XX}^{71}$. Jest inną kwestią, czy przemiany dziewiętnastowieczne nie były początkiem procesów, które doprowadziły do znacznego osłabienia chrześcijaństwa w Europie w drugiej połowie XX w.; w takim wypadku można mówić o zjawiskach dechrystianizacyjnych w wieku poprzednim, tyle że byłaby to bomba z opóźnionym zapłonem. Takie stwierdzenie wydaje mi się jednak niesłychanie trudne do udowodnienia bądź obalenia i nie wiem, czy nie należałoby ono bardziej do sfery historiozofii

${ }^{71}$ Co bardzo mocno podkreśla T. Nipperdey, op. cit., s. 403. 
niż badań historycznych. Tak czy owak, wykracza ono poza ramy chronologiczne tego szkicu.

Skłonny jestem uznać, razem z Bergerem ${ }^{72}$, że teoria sekularyzacji niewiele pomaga w zrozumieniu zjawisk historycznych - nawet jeśli nie jest jednoznacznie błędna, jest ogromnie jednostronna. Pomijając niejasność samego pojęcia (jakie pojęcie w humanistyce jest jasne?), wyjmuje ona pewne zjawiska $\mathrm{z}$ kontekstu. Jeden z badaczy zwrócił na przykład uwagę, że analizując spadek praktyk religijnych w XX w., trzeba zwrócić uwagę, iż wiek ten był w ogóle wiekiem spadku partycypacji we wszystkich instytucjach społecznych - partiach, klubach, stowarzyszeniach czy związkach. Spadek uczestnictwa w związkach wyznaniowych, tam, gdzie występował, jest więc częścią tego szerszego trendu, a nie odrębnym zjawiskiem ${ }^{73}$. Jeśli teoria sekularyzacji jest akceptowalna, to pod warunkiem, że sekularyzację będziemy rozumieć w sensie węższym, jako rozdzielenie sfery państwowej i religijnej. (Tak rozumieją sekularyzację redaktorzy cytowanego wyżej tomu o sekularyzacji w czeskich ziemiach w XIX w.). Istnienie takiej sekularyzacji w wieku pary i elektryczności nie ulega wątpliwości, ale nie ma to nic wspólnego z problemem wzrostu lub osłabienia intensywności życia religijnego - a więc jeśli chodzi o tematykę niniejszego szkicu, pozostajemy w punkcie wyjścia.

Jeśli chodzi zaś o popularne łączenie sekularyzacji ze wzrostem racjonalizmu, to rzecz w moim przekonaniu przedstawia się następująco: w rozumieniu dosłownym ta teza jest na pewno fałszywa. Nie ma żadnych danych dla poglądu, że ludzie obecnie zachowują się racjonalniej niż w jakiejkolwiek innej epoce. Aforyzm, błędnie przypisywany Gilbertowi K. Chestertonowi (ale trafnie streszczający jego poglądy) trafia, jak sądzę, w sedno sprawy: ,When a man stops believing in God he doesn't then believe in nothing, he believes anything"74. Być może dechrystianizacja, o ile zachodzi, wynika z osłabienia raczej niż wzmocnienia racjonalizmu: masowa kultura odchodzi od religii nie dlatego, że ogół społeczeństwa staje się coraz bardziej racjonalny, lecz przeciwnie - dlatego, że religia z jej

${ }^{72}$ P.L. Berger, op. cit. Trzeba podkreślić, że w swych nowszych pracach Berger widzi tę kwestię inaczej niż w swej najważniejszej pracy z dziedziny socjologii religii sprzed prawie pięćdziesięciu lat The Sacred Canopy, w której skłonny był akceptować teorię sekularyzacji. Zob. P.L. Berger, Święty baldachim. Elementy socjologicznej teorii religii, Kraków 1998 (oryg. ang. 1967).

${ }^{73}$ J.C.D. Clark, Secularization and Modernization: The Failure of a Grand Narrative, „The Historical Journal" 55, 2012, 1, s. 161-194 (tutaj: s. 164).

${ }^{74}$ Apokryficzny cytat $\mathrm{z}$ Chestertona oparty jest prawdopodobnie na dwóch sformułowaniach z opowiadania The Oracle of the Dog. Zob. dyskusję na temat pochodzenia tego cytatu na stronie The American Chesterton Society, 〈http://www.chesterton. org/ceases-to-worship/> (dostęp: 13 I 2015). 
wyrafinowanym systemem teologicznym, problemami filozoficznymi itp. jest trudniejsza do przyjęcia niż wiara w latające spodki czy - aby trzymać się wieku XIX - okultyzm. W tym sensie Max Weber nie miał racji: żadne odczarowanie świata nie następuje w nowożytności. Jeśli chodzi o postawy indywidualne, to rzecz wydaje mi się oczywista.

Ale koncepcja postępu racjonalizacji nie da się utrzymać także na poziomie instytucji społecznych. Weber sądził, że biurokratyczny system zachodnich państw nowoczesnych jest w jakiś sposób bardziej racjonalny niż inne systemy społeczne; myślę, że nie ma żadnych podstaw do takiej opinii ${ }^{75}$.

Jeśli teza o odczarowaniu miałaby się ostać, to tylko na poziomie psychologicznym, a nie filozoficznym. Można argumentować następująco: ludzie obecnie uważają się za racjonalnych, mówią o rozumie jako o najwyższym autorytecie, co wcale nie przekłada się na racjonalność ich zachowań. Ta interpretacja jest warta rozważenia, ale wtedy mielibyśmy sytuację, w której mit racjonalizmu, a nie sam racjonalizm, zajmuje miejsce religii.

Durkheim sądził, że miejsce dla religii - nie tej czy innej, ale religii jako takiej - będzie w kulturze ludzkiej zawsze, a uzasadniał tę myśl następująco: nawet założywszy, że racjonaliści słusznie sądzą, iż rozwój nauki zmniejsza miejsce dla wiary (a Durkheim zdaje się przytakiwać tej koncepcji), nauka, rozwijając się, nigdy nie tworzy systemu w pełni spójnego. Nowe obserwacje i nowe idee muszą być zinterpretowane i wbudowane w system myślenia naukowego, a przez czas, w jakim się to dokonuje, pojawiają się kolejne obserwacje i kolejne idee, i tak dalej - sytuacji pełnej spójności nie ma nigdy. Ludzie jednak chcą spójnego światopoglądu - a dostarczyć go może jedynie religia ${ }^{76}$. Sadzę, że argument ten jest trafny i wystarcza zupełnie, aby odrzucić tezę o koniecznej sekularyzacji. Być może pojęcie zmiennych form symbiozy religii i kultury świeckiej czy też wprowadzona w tytule tego szkicu nieco żartobliwa metafora małżeństwa z rozsądku byłyby tu najwłaściwsze.

${ }^{75}$ W tym wypadku zgadzam się z krytyką Stanisława Kozyr-Kowalskiego, Weberowska socjologia religii a teoria społeczeństwa jako całości, w: M. Weber, Szkice z socjologii religii, oprac. S. Kozyr-Kowalski, Warszawa 1984, s. 7-68, tutaj s. 25-26. Podobnie krytykuje Weberowską koncepcję racjonalizmu Jonathan C.D. Clark, op. cit., s. 177.

${ }^{76}$ E. Durkheim, Elementarne formy życia religijnego. System totemiczny w Australii, Warszawa 2010 (oryg. franc. 1912), s. 369-370. 


\section{A Marriage of Convenience: the Roman Catholic Church and Modernity in Nineteenth-Century Europe}

This paper examines the problem of Dechristianization and secularization in nineteenth-century Europe, with a special emphasis on the Roman Catholic Church's ways of reacting to modernity. The first part deals with changes in religious attitudes, on individual and collective levels, in the midst of rapid social and intellectual changes that took place in the nineteenth century. The building of the modern secular state structures was among the most important factors that weakened the position of the established churches.

The second part deals with the Roman Catholic Church. The argument is that the Church managed to come to terms with modernity and to escape secularization at the price of supporting modern radical nationalism in the early twentieth century. The Church, especially since the times of Pope Leo XIII, chose to embrace modernity in its conservative form as an alternative to the dominant rationalist-liberal type. It was a modernity nevertheless, and the transformations of the Catholic Church through the nineteenth and early twentieth century should be understood in terms of modernization (although an unenthusiastic one) rather than a resistance to modernity. The problem of Catholic liberalism and the reasons for its rather moderate influence is also discussed. On the whole, Peter Berger was right that "modernity is not necessarily secularizing; it is necessarily pluralizing", i.e. it creates various possibilities of behaviour that can, but do not have to, lead to secularization. 